\title{
Stoichiometric Model of Escherichia coli Metabolism: Incorporation of Growth-Rate Dependent Biomass Composition and Mechanistic Energy Requirements
}

\author{
J. Pramanik, J . D. Keasling \\ Department of Chemical Engineering, University of California, Berkeley, CA \\ 94720-1462; telephone: 510-642-4862; e-mail: \\ keasling@socrates.berkeley.edu
}

Received 26 November 1996; accepted 2 April 1997

\begin{abstract}
A stoichiometric model of metabolism was developed to describe the balance of metabolic reactions during steady-state growth of Escherichia coli on glucose (or metabolic intermediates) and mineral salts. The model incorporates 153 reversible and 147 irreversible reactions and 289 metabolites from several metabolic data bases for the biosynthesis of the macromolecular precursors, coenzymes, and prosthetic groups necessary for synthesis of all cellular macromolecules. Correlations describing how the cellular composition changes with growth rate were developed from experimental data and were used to calculate the drain of precursors to macromolecules, coenzymes, and prosthetic groups from the metabolic network for the synthesis of those macromolecules at a specific growth rate. Energy requirements for macromolecular polymerization and proofreading, transport of metabolites, and maintenance of transmembrane gradients were included in the model rather than a lumped maintenance energy term. The underdetermined set of equations was solved using the Simplex algorithm, employing realistic objective functions and constraints; the drain of precursors, coenzymes, and prosthetic groups and the energy requirements for the synthesis of macromolecules served as the primary set of constraints. The model accurately predicted experimentally determined metabolic fluxes for aerobic growth on acetate or acetate plus glucose. In addition, the model predicted the genetic and metabolic regulation that must occur for growth under different conditions, such as the opening of the glyoxylate shunt during growth on acetate and the branching of the tricarboxylic acid cycle under anaerobic growth. Sensitivity analyses were performed to determine the flexibility of pathways and the effects of different rates and growth conditions on the distribution of fluxes. (c) 1997 J ohn Wiley \& Sons, Inc. Biotechnol Bioeng 56: 398-421, 1997.
\end{abstract}

Keywords: Escherichia coli; metabolism; flux; linear optimization

\section{INTRODUCTION}

A central problem in metabolic engineering is understanding how the cell balances its energy and biosynthetic needs

Correspondence to: Jay Keasling

Contract grant sponsor: NSF

Contract grant number: BES-9502495 (catabolism and anabolism) for optimal growth under various conditions. Simple carbon sources and mineral salts are taken into the cell and transformed into the complex biopolymers and cofactors that compose the cell, while generating the metabolic energy necessary to make these complex biomolecules.

There have been many attempts to study regulation of metabolism using mathematical models. The simplest description of cellular metabolism uses order of magnitude calculations to determine the metabolic yields from cell composition, measured substrate uptake and product synthesis, and growth rates (Blanch and Clark, 1996; Savinell et al., 1989). However, this analysis provides limited formation about the fluxes of intermediary metabolism. A more detailed analysis uses the stoichiometry of biochemical pathways and cell composition data to estimate the steady-state mass and energy distributions (Nissen et al., 1997; Savinell and Palsson, 1992a; Tsai et al., 1988; Vallino and Stephanopoulos, 1993; Varma et al., 1993); experimentally determined intermediary fluxes can be used as constraints to improve the accuracy of calculations. The most detailed level of metabolic pathway analysis examines the dynamic behavior of cell metabolism and requires kinetic and thermodynamic data, most of which is currently unavailable: kinetic parameter measurements are difficult to obtain and kinetic models developed from in vitro measurements may not apply in vivo.

Metabolic modeling, based on the stoichiometry of the reactions, does not require kinetic parameters and information about the kinetic mechanism of each enzyme. The growth kinetics of the cell are incorporated into the model through the energy and biomass requirements, which are functions of the growth rate. The stoichiometry of metabolism is well defined and variations among different cells are limited to a few reactions. There are two different methods of using stoichiometry to study bioreaction networks. The first method reduces the stoichiometric matrix to an overdetermined form and then uses linear regression to find the flux distribution (Tsai et al., 1988; Vallino and Stephanopoulos, 1993). Independent measurements must be added 
or a number of reactions must be removed or constrained to render the matrix nonsingular. Unfortunately, the pathways neglected for mathematical reasons may, in fact, be active. Removing entire pathways may cause large changes in the calculated fluxes. Several previous models solved an overdetermined system by constraining the stoichiometric matrix through inspection (Papoutsakis, 1984, Tsai et al., 1988).

The second method optimizes an underdetermined matrix using different objective functions and allows retention of the entire network. Applications of this approach to a subset of hybridoma, yeast, and Escherichia coli metabolism demonstrated the utility of this technique (Majewski and Domach, 1990; Savinell et al., 1989; Savinell and Palsson, 1992a,b; van Gulik and Heijnen, 1995; Varma and Palsson, 1993, 1994a,b; 1995; Varma et al., 1993). Majewski and Domach were able to predict the secretion of acetate during growth of E. coli on glucose (Majewski and Domach, 1990). Varma and Palsson showed the effect of oxygen availability on acetate secretion and the metabolic capabilities of $E$. coli to overproduce amino acids and other products (Varma and Palsson, 1993; 1994a,b; 1995; Varma et al., 1993). However, in all of these cases, the metabolic pathways were not complete, numerous reactions were lumped, and there was no accounting for the effects of growth rate on cellular composition and energy requirements.

We developed a detailed stoichiometric model of $E$. coli metabolism that includes a more complete data base of known reactions involved in the catabolism of glucose, acetate, or tricarboxylic acid (TCA) cycle intermediates. None of the pathways are lumped to reduce the matrix so that any future simulations studying deletions or mutations in pathways would not require generation of an entirely new stoichiometric matrix. A detailed stoichiometric matrix allows us to study deletions or mutations of individual enzymes by setting constraints of the flux values for those enzymes. The model uses the precursor requirements (calculated from the known composition of the bacterial cell) (Neidhardt et al., 1990) and solves for the fluxes through the internal metabolic pathways using linear optimization. Rather than include a "maintenance energy" term, energy demands for growth are calculated from mechanistic energy requirements for macromolecular polymerization and proofreading, transport of metabolites, and maintenance of transmembrane gradients. Experimental data on nutrient uptake and secretion can be incorporated into the model. The model is solved using linear optimization and predicts the metabolic regulation observed during growth under different conditions and on different carbon sources.

\section{MODEL DEFINITION}

The basis for this flux-based model of metabolism is a mass balance on the metabolites in E. coli,

$$
\frac{d \mathbf{x}}{d t}=\mathbf{S} \cdot \mathbf{v}-\mathbf{b}
$$

where $\mathbf{x}$ is the vector of metabolite concentrations $(n \times 1$ dimension), $\mathbf{S}$ is the stoichiometric matrix $(n \times m$ dimension), $\mathbf{v}$ is a vector of reaction rates or fluxes through the metabolic reactions ( $m \times 1$ dimension), and $\mathbf{b}$ is the vector for consumption and secretion rates of metabolites and for biosynthetic requirements for cellular macromolecules $(n \times$ 1 dimension). Under balanced growth conditions, the concentrations of intracellular metabolites are constant with time:

$$
\mathbf{S} \cdot \mathbf{v}=\mathbf{b} \text {. }
$$

The goal of this model is to determine how mass and energy is allocated within the network of metabolic reactions $(\mathbf{v})$. We begin with descriptions of the composition of the cell (which determines b) and of the reactions involved in synthesizing the precursors and energy required for growth (which determine $\mathbf{S}$ ).

\section{Biomass and Energy Requirements}

An average $E$. coli $\mathrm{B} / \mathrm{r}$ cell growing exponentially at $37^{\circ} \mathrm{C}$ under aerobic conditions in glucose minimal medium with a doubling time of approximately $40 \mathrm{~min}$ has a dry weight of $2.8 \times 10^{-13} \mathrm{~g}$. The dry weight is $55 \%$ protein, $20.5 \%$ RNA, $3.1 \%$ DNA, $9.1 \%$ lipids, $3.4 \%$ lipopolysaccharides, $2.5 \%$ peptidoglycan, $2.5 \%$ glycogen, $0.4 \%$ polyamines, and $3.5 \%$ other metabolites, cofactors, and ions (Neidhardt, 1987). The types and amounts of precursors required to synthesize these macromolecules at a given growth rate were determined from the composition of each of the macromolecules: the amino acid composition of proteins and the nucleotide composition of RNA and DNA are listed in Table I, the phospholipid composition in Table II, and the fatty acid composition in Table III. The amounts of cofactors and energy carriers present per gram dry weight (DW) of biomass are listed in Table IV. The b vector contains these precursor requirements to account for synthesis of the cellular macromolecules.

In addition to the precursors required to synthesize macromolecules, energy and reducing equivalents are also required for growth. Table $\mathrm{V}$ presents the energy requirements for $1 \mathrm{~g}$ of $E$. coli $\mathrm{B} / \mathrm{r}$ cells growing aerobically with a 40-min doubling time at $37^{\circ} \mathrm{C}$ in glucose minimal medium. The energy requirements for DNA production include that needed by helicase to unwind the helix, the synthesis of the primer RNA to Okazaki fragments and ligation of the fragments, proofreading by DNA polymerase III, adjustment of the torsional tension of each chromosomal domain, and methylation of newly synthesized DNA (Neidhardt et al., 1990). The energy requirements for stable RNA production include that for discarding segments of primary transcripts and that for modifications (Neidhardt et al., 1990). The energy requirements for protein synthesis include that for mRNA synthesis, charging tRNAs with amino acids and incorporation of amino acids into protein, and proofreading, assembly, and modification of the protein (Neidhardt et al., 
Table I. Precursor requirements for synthesis of 40-min cell.

\begin{tabular}{|c|c|c|}
\hline Component & Percent & $\mu \mathrm{mol} / \mathrm{g} \mathrm{DW}$ \\
\hline \multicolumn{3}{|l|}{ Amino acids } \\
\hline Ala & 9.60 & 488 \\
\hline Arg & 5.53 & 281 \\
\hline Asn & 4.51 & 229 \\
\hline Asp & 4.51 & 229 \\
\hline Cys & 1.71 & 87 \\
\hline Glu & 4.92 & 250 \\
\hline Gln & 4.92 & 250 \\
\hline Gly & 4.92 & 582 \\
\hline His & 1.77 & 90 \\
\hline Ile & 5.43 & 276 \\
\hline Leu & 8.42 & 428 \\
\hline Lys & 6.42 & 326 \\
\hline Met & 2.87 & 146 \\
\hline Phe & 3.46 & 176 \\
\hline Pro & 4.13 & 210 \\
\hline Ser & 4.03 & 205 \\
\hline Thr & 4.74 & 241 \\
\hline Trp & 1.06 & 54 \\
\hline $\mathrm{Tyr}$ & 2.58 & 131 \\
\hline Val & 7.91 & 402 \\
\hline \multicolumn{3}{|l|}{ rNTPs } \\
\hline ATP & 26.2 & 165 \\
\hline GTP & 32.2 & 203 \\
\hline CTP & 20.0 & 126 \\
\hline UTP & 21.6 & 136 \\
\hline \multicolumn{3}{|l|}{ dNTPS } \\
\hline dATP & 24.7 & 24.7 \\
\hline dGTP & 25.4 & 25.4 \\
\hline dCTP & 25.4 & 25.4 \\
\hline TTP & 24.7 & 24.7 \\
\hline
\end{tabular}

Amino acids, ribonucleotide triphosphates (rNTPs), and deoxyribonucleotide triphosphates (dNTPs) are given in percentage of the biopolymer and as micromoles per gram dry weight $(\mu \mathrm{mol} / \mathrm{g} \mathrm{DW})$ of cells (Neidhardt, 1987).

1990). These energy requirements were also included in the b vector.

\section{Growth-Rate Dependence of Cell Composition}

The macromolecular composition and energy requirements listed above are not the same for cells growing at different rates. For example, RNA content increases with growth rate whereas DNA and protein contents decrease with the growth rate (Bremer and Dennis, 1996; Brunschede et al., 1977). To solve for the fluxes through the metabolic reactions for doubling times other than $40 \mathrm{~min}$, correlations were developed from experimental data for RNA, DNA, protein, surface area (for membrane components), and glycogen content as a function of specific growth rate $(\mu)$ for exponentially growing cells or dilution rate for continuous cultures (Fig. 1, Table VI). As the macromolecular composition of the cell changes with growth rate, so must the energy requirements to synthesize these macromolecules, which were correlated with the macromolecular needs (Fig. 2 ). Because protein is one of the most energetically expensive macromolecules and because the relative amount of protein decreases with increasing growth rate, the total energy expended by the cell (per g DW) actually decreases with growth rate.

\section{Metabolic Pathways}

The transformation of a simple carbon source and mineral salts to the biomass and energy requirements for growth is facilitated through the metabolic reactions. The stoichiometric matrix $\mathbf{S}$ contains the stoichiometry of all reactions incorporated into the model. Included in this model were 153 reversible and 147 irreversible reactions (Appendix A) and 289 metabolites (Appendix B) compiled primarily from three sources: the Boehringer-Mannheim wall chart (Michal, 1993), chapters 14-19, 24-41, 44, 48, 49, 67, 69, 72, 75, and 87 of Neidhardt et al. (1996), and the Ecocyc data base (Karp et al., 1996). There are discrepancies between the number of reactions included in this model and the Ecocyc data base because a number of reactions in the Ecocyc data base have the same product but alternative substrates (e.g., $\mathrm{NH}_{4}{ }^{+}$versus glutamine as a source for nitrogen) when only one of these is known to be used under physiological conditions in E. coli. Finally, a number of transport reactions were included in the model to account for uptake or secretion of inorganics or metabolites. In many cases, these transport steps deplete or enhance the transmembrane proton gradient.

Table II. Phospholipid composition of E. coli strains.

\begin{tabular}{|c|c|c|c|c|c|c|c|c|c|}
\hline \multirow{2}{*}{$\begin{array}{l}\text { Specific growth rate } \\
\qquad\left(\mathrm{h}^{-1}\right)\end{array}$} & \multicolumn{3}{|c|}{1.3} & \multicolumn{3}{|c|}{1.04} & \multicolumn{3}{|c|}{0.92} \\
\hline & PE\% & PG\% & CL\% & PE\% & PG\% & CL\% & PE\% & PG\% & CL\% \\
\hline \multicolumn{10}{|l|}{ Strains } \\
\hline E. coli $\mathrm{B} / \mathrm{r}$ & & & & 75.0 & 18.0 & 5.0 & & & \\
\hline E. coli $\mathrm{B} / \mathrm{r}$ & 77.0 & 21.3 & 1.1 & & & & 78.0 & 20.4 & 1.5 \\
\hline E. coli $\mathrm{B} / \mathrm{r}$ & 74.8 & 20.6 & 2.3 & & & & 75.1 & 20.3 & 1.9 \\
\hline E. coli AX14 & 71.3 & 19.2 & 3.4 & & & & 69.5 & 19.4 & 4.6 \\
\hline E. coli $\mathrm{K}-12$ & 67.1 & 18.7 & 5.1 & & & & 68.8 & 19.3 & 5.7 \\
\hline Overall average & 73.0 & 19.7 & 3.4 & & & & 72.8 & 19.8 & 3.4 \\
\hline Overall SD & 3.9 & 1.0 & 1.8 & & & & 4.4 & 0.6 & 2.0 \\
\hline
\end{tabular}

Data for a specific growth rate of $1.04 \mathrm{~h}^{-1}$ are from Neidhardt (1987). All other data are from Ballesta and Schaechter (1971). PE, phosphatidylethanolamine; PG, phosphatidylglycerol; CL, cardiolipin. 
Table III. Fatty acid composition of E. coli lipids.

\begin{tabular}{|c|c|}
\hline Fatty acid & $\begin{array}{c}\text { Total fatty acid } \\
(\%)\end{array}$ \\
\hline Myristic acid, 14:00 & 2.68 \\
\hline Myristoleic acid, 14:01 & 7.70 \\
\hline Palmitic acid, 16:00 & 38.23 \\
\hline Palmitoleic acid, 16:01 & 10.74 \\
\hline Heptadecenoic acid, $17 \Delta$ & 16.11 \\
\hline cis-Vaccenic acid, 18:00 & 0.90 \\
\hline Oleic acid, 18:01 & 17.91 \\
\hline Nonadecenoic acid, $19 \Delta$ & 5.73 \\
\hline
\end{tabular}

Data from Bright-Gaertner and Proulx (1972), Kanemasa et al. (1967), Mavis and Vagelos (1972), and Neidhardt (1987).

Although the stoichiometry of most biosynthetic reactions is well known, the required cofactor(s) for a particular reaction may not be so well known. When known, correct NADH or NADPH was used in the stoichiometry of a reaction. When it was known that NADP/NADPH and NAD/ NADH could be used interchangeably for the same reaction, pathways for both reactions were included; however, if no information was available to determine which electron carrier is used, it was assumed that NAD/NADH was used for anabolism and NADP/NADPH was used for catabolism.

In contrast to most of the biosynthetic reactions that have well-known stoichiometry, the pathways involved in electron transport and oxidative phosphorylation have variable stoichiometry due to the use of different dehydrogenases and cytochromes: the NADH dehydrogenases NDH-I and $\mathrm{NDH}-\mathrm{II}$ transport $2 \mathrm{H}^{+} / \mathrm{e}^{-}$and $0 \mathrm{H}^{+} / \mathrm{e}^{-}$, respectively (Gennis and Stewart, 1996); the cytochromes cyt bd and cyt bo3 transport $1 \mathrm{H}^{+} / \mathrm{e}^{-}$and $2 \mathrm{H}^{+} / \mathrm{e}^{-}$, respectively (Gennis and Stewart, 1996); the number of $\mathrm{H}^{+}$transported into the cell by the membrane bound $\mathrm{H}^{+}$-ATPase to phosphorylate ADP has been estimated as $2-4$, with 3 being the most likely (Harold and Maloney, 1996). Pathways for all possible stoichiometries were incorporated into the model. Thus, the $\mathrm{P} / \mathrm{O}$ ratio can be a noninteger value (Neidhardt et al., 1990), because it is a function of multiple enzymes being used in parallel for respiration. The model simulates the noninteger $\mathrm{P} / \mathrm{O}$ ratios by incorporating all known respiration pathways

Table IV. Amounts of cofactors, energy carriers, and other molecules in E. coli.

\begin{tabular}{lc}
\hline \multicolumn{1}{c}{ Metabolite } & $\mu \mathrm{mol} / \mathrm{g} \mathrm{DW}$ \\
\hline 5-Methyl-THF & 50.0 \\
Putrescine & 35.0 \\
Spermidine & 7.0 \\
NAD & 2.15 \\
NADH & 0.05 \\
NADP & 0.13 \\
NADPH & 0.4 \\
UDP-Glucose (soluble pool) & 3.0 \\
ATP (soluble pool) & 4.0 \\
ADP (soluble pool) & 2.0 \\
AMP (soluble pool) & 1.0 \\
\hline
\end{tabular}

Data from Lowry et al. (1971) and Penfound and Foster (1996).
Table V. Energy requirements for polymerization and processing of macromolecules.

\begin{tabular}{|c|c|c|}
\hline Process & $\begin{array}{l}\text { Energy } \\
\text { required }\end{array}$ & Reference \\
\hline \multicolumn{3}{|l|}{ Protein synthesis and processing ${ }^{a}$} \\
\hline Activation and incorporation & 4.0 & Neidhardt et al., 1990 \\
\hline mRNA synthesis & 0.2 & Neidhardt et al., 1990 \\
\hline Proofreading & 0.1 & Neidhardt et al., 1990 \\
\hline Assembly and modification & 0.006 & Neidhardt et al., 1990 \\
\hline \multicolumn{3}{|l|}{ RNA synthesis and processing ${ }^{b}$} \\
\hline Discarding segments & 0.38 & Neidhardt et al., 1990 \\
\hline Modification & 0.02 & Neidhardt et al., 1990 \\
\hline \multicolumn{3}{|l|}{ DNA synthesis and processing ${ }^{b}$} \\
\hline Unwinding helix & 1.0 & Neidhardt et al., 1990 \\
\hline Proofreading & 0.36 & Neidhardt et al., 1990 \\
\hline Discontinuous synthesis & 0.006 & Neidhardt et al., 1990 \\
\hline Negative supercoiling & 0.005 & Neidhardt et al., 1990 \\
\hline Methylation & 0.001 & Neidhardt et al., 1990 \\
\hline \multicolumn{3}{|l|}{ Membrane processes ${ }^{c}$} \\
\hline Proton leakage & 62.9 & Maloney, 1987 \\
\hline
\end{tabular}

Data from Neidhardt et al. (1990).

${ }^{\mathrm{a}} \mu \mathrm{mol}$ ATP $/ \mu \mathrm{mol}$ amino acid.

${ }^{\mathrm{b}} \mu \mathrm{mol}$ ATP/ $\mu \mathrm{mol}$ nucleotide.

${ }^{c} \mu \mathrm{mol} \mathrm{H} \mathrm{H}^{+} / \mathrm{g}$ DW h.

into the stoichiometric matrix and allowing fluxes through multiple pathways simultaneously.

\section{Solution Method}

For the system described above, the number of reactions $(m)$ is greater than the number of metabolites $(n)$. Because multiple solutions exist, linear optimization was used to determine the fluxes (v). Linear optimization requires objective functions for solution:

$$
\text { minimize/maximize: } \quad Z=\sum_{i} c_{i} v_{i}
$$

where $c_{i}$ are the weights and $v_{i}$ are the elements of the flux vector. Some of the objective functions that were used included minimization or maximization of ATP usage, substrate uptake, growth rate, and product synthesis. Typically, maximization of growth rate and minimization or maximization of metabolite secretion were used as objective functions.

For the objective of maximizing growth rate, the flux of precursors for a biomass composition corresponding to a particular growth rate was calculated using the relationships in Table VI. The amount of each precursor per unit time necessary for synthesis of biomass at a particular growth rate was used as the upper bound for the flux of each precursor, and the lower bound was set to zero. Then the model was forced to maximize the synthesis rate of each precursor for biomass composition, such as individual amino acids, nucleotides, and glycogen monomer units. If the model was unable to match the necessary flux of one or more of the precursors for a biomass composition consistent with a particular growth rate, the biomass composition was recalculated at another growth rate based on the precursor metabo- 

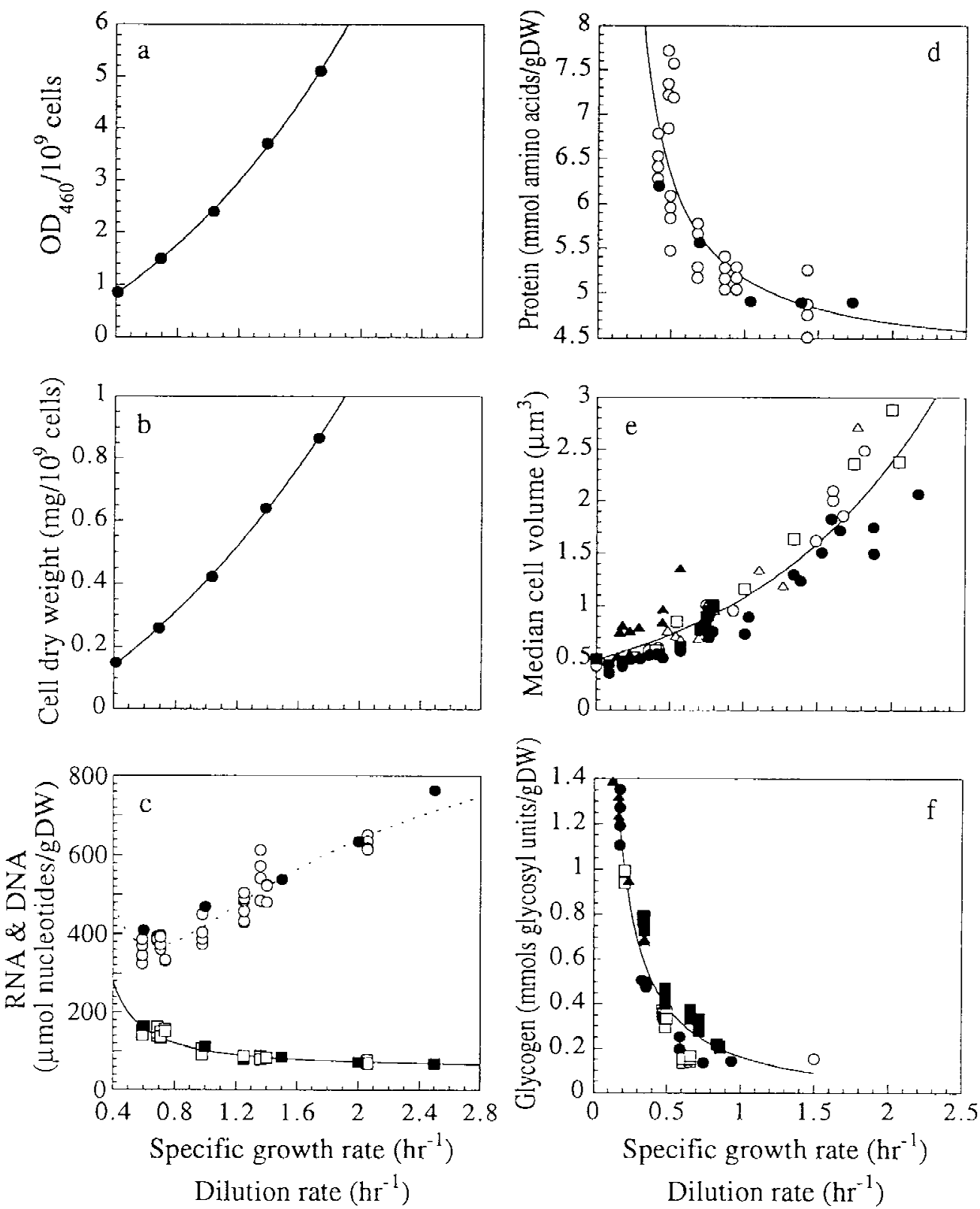

Figure 1. Variation in macromolecular composition and size of $E$. coli with growth rate. The equations in Table VI were fit to the data (lines in each plot). (a) Optical density per $10^{9}$ cells as a function of specific growth rate (Bremer and Dennis, 1987). (b) Dry cell weight per 109 cells as a function of specific growth rate (Bremer and Dennis, 1987). (c) RNA and DNA ( $\mu$ mol per g DW) as a function of specific growth rate. Circles: RNA. Squares: DNA. Open symbols are from Brunschede et al. (1977). Closed symbols are from Bremer and Dennis (1987). (d) Protein (mmol per g DW) as a function of specific growth rate. Open symbols are from Brunschede et al. (1977). Closed symbols are from Bremer and Dennis (1987). (e) Median cell volume ( $\mu m^{3}$ ) as a function of specific growth rate (Bremer and Dennis, 1987; Eckert and Schaechter, 1965; Shehata and Marr, 1971). (f) Glycosyl units (mmol per g DW) as a function of dilution rate. Circles are from Neidhardt (1987). All other data are from Holme (1957).

lite that was not synthesized at the rate calculated from the correlations. The model was resolved with the new biomass composition. If the synthesis fluxes were consistent with biomass composition at that growth rate, then the case was considered biologically feasible. Otherwise, the iterative procedure was repeated until the appropriate biomass requirements could be balanced for a particular carbon and energy source and growth rate.

In addition to the objective function, optimization requires constraints. Equation (2) served as one set of constraints. This constraint states that the mass balance must be satisfied and no accumulation of metabolites is allowed. Another set of constraints included the minimum $\left(\alpha_{i}\right)$ and/or maximum $\left(\beta_{i}\right)$ of allowable fluxes:

$$
\alpha_{i}<v_{i}<\beta_{i} \quad i=1,2,3, \ldots, m \text {. }
$$

Because fluxes were defined as positive values only, the individual fluxes had a lower limit of zero and an upper limit of infinity. Reversible reactions were divided into two positive reactions in opposite directions. Experimental data for individual fluxes can be used as either lower and/or 
Table VI. Equations for growth-rate dependent biomass composition.

\begin{tabular}{|c|c|c|}
\hline Component & Correlation & Reference \\
\hline $\begin{array}{l}\text { Optical density } \\
\qquad\left(\mathrm{OD}_{460} / 10^{9} \text { cells }\right)\end{array}$ & $-2.688+2.748 \cdot 2^{0.869 \mu}$ & $\begin{array}{l}\text { Calculated from data in } \\
\text { Figure 1(a) }\end{array}$ \\
\hline Cell mass $\left(10^{-12} \mathrm{~g} \mathrm{DW}\right)$ & $-0.636+0.635 \cdot 2^{0.718 \mu}$ & $\begin{array}{l}\text { Calculated from data in } \\
\text { Figure } 1(\mathrm{~b})\end{array}$ \\
\hline $\begin{array}{l}\mathrm{RNA}^{\mathrm{a}, \mathrm{b}} \\
\qquad(\mu \mathrm{mol} \text { NTPs/g DW })\end{array}$ & $1139.5-\frac{966.5}{\mu} \cdot 2^{-0.665 / \mu}$ & $\begin{array}{l}\text { Calculated from data in } \\
\text { Figure 1(c) }\end{array}$ \\
\hline $\begin{array}{l}\text { DNA }^{\mathrm{b}} \\
\quad(\mu \mathrm{mol} \text { dNTPs/g DW })\end{array}$ & $\frac{100 \cdot \mu}{0.023}\left(2^{(0.017+0.663) / \mu}-2^{0.663 / \mu}\right)$ & $\begin{array}{l}\text { Calculated from data in } \\
\text { Figure } 1(\mathrm{c})\end{array}$ \\
\hline $\begin{array}{l}\text { Protein }^{\mathrm{b}} \\
\qquad(\mathrm{mmol} \mathrm{AAs} / \mathrm{g} \mathrm{DW})\end{array}$ & $4.228 \cdot 2^{0.288 / \mu}$ & $\begin{array}{l}\text { Calculated from data in } \\
\text { Figure } 1(\mathrm{~d})\end{array}$ \\
\hline Cell volume $\left(\mu \mathrm{m}^{3}\right)$ & $0.486 \cdot 2^{1.144 \mu}$ & $\begin{array}{l}\text { Calculated from data in } \\
\text { Figure } 1(\mathrm{e})\end{array}$ \\
\hline Cell radius $(R)(\mu \mathrm{m})$ & $0.293 \cdot 2^{0.41 \mu}$ & \\
\hline Cell length $(L)(\mu \mathrm{m})$ & $2 \cdot 2^{0.333 \mu}$ & $\begin{array}{l}\text { Donachie and Robinson, } \\
1987\end{array}$ \\
\hline Surface area ${ }^{c}\left(\mu m^{2}\right)$ & $2 \pi R(L-2 R)+4 \pi R^{2}$ & \\
\hline $\begin{array}{l}\text { Glycogen } \\
\text { (glycosyl units) }\end{array}$ & $10^{3}\left(1-2^{-3.24 \cdot 10^{4} / \mu}\right)$ & $\begin{array}{l}\text { Calculated from data in } \\
\text { Figure 1f }\end{array}$ \\
\hline
\end{tabular}

${ }^{\mathrm{a}}$ It has been speculated that the increase in the RNA content with growth rate is due to the larger fraction of stable RNA (rRNA, tRNA) necessary for the increase in protein production rate.

${ }^{\mathrm{b}}$ Although the amino acid and nucleotide compositions of protein and DNA and RNA, respectively, may vary under different growth conditions, the amino acid and nucleotide fractions were available for only a cell with a 40-min doubling time (Fig. 1); it was assumed that this composition was maintained at all growth rates.

'The radius and length are then used to calculate the surface area $(A)$ of the cell, assuming that the cell is a cylinder with hemispherical caps. The lipid composition was calculated from the surface area. For a cell with a 40-min doubling time, phosphatidylethanolamine makes up $75 \%$ of these lipids, phosphatidylglycerol 18\%, and cardiolipin 5\% with only trace amounts of phosphatidylserine (Table II) (Ballesta and Schaechter, 1971; Neidhardt, 1987). The lipopolysaccharide content of the 40-min cell is $8.4 \mu \mathrm{mol} / \mathrm{g}$ DW and the peptidoglycan content is $8.4 \mu \mathrm{mol} / \mathrm{g} \mathrm{DW}$ (Neidhardt, 1987). The fatty acid composition found in total lipids is presented in Bright-Gaertner and Proulx (1972), Kanemasa et al. (1967), Mavis and Vagelos (1972), and Neidhardt (1987). Because the lipid and fatty acid composition was available for only a cell with 40-min doubling time, it was assumed that the composition did not change with growth rate (data from Table III averaged).

upper constraints, or the flux value can be set to the value of the experimental data. Because a range of values is allowed for the individual flux constraints, variability in experimental data can be incorporated into the model. In this model the internal fluxes were not constrained because the goal was to predict the fluxes and compare them with experimental data.

The model was solved using the Simplex subroutines in the OSL package (IBM, 1992). This package has a number of important features: it has several alternative solution methods, it has been optimized for very large problems, and it enables the performance of a extensive sensitivity analysis.

\section{Sensitivity Analysis}

The basis matrix for each case (B) is a nonsingular subset of the stoichiometric matrix corresponding to the elements of $\mathbf{v}$ $\left(\mathbf{v}_{\mathbf{B}}\right)$, which uniquely solve the equation.

$$
\text { B } \cdot \mathbf{v}_{B}=\mathbf{b} \text {. }
$$

Two types of sensitivity analysis can be performed on the solution. The first type determines what changes are required in the row and column bounds to cause the optimum solution to occur with a different basis. That is, it examines how constrained a given reaction is in order to achieve a given objective using the same basis matrix. If a reaction is bounded tightly with respect to the basis matrix, it means that the basis matrix is very dependent on the flux value through that reaction and so is the simulation solution. The second type of analysis determines how large a change is required in the objective function coefficients to cause the optimum solution to occur with a different basis. This type of analysis gives rise to "reduced costs" (Luenberger, 1984).

\section{RESULTS}

\section{Model Predictions Compared to Experimental Data}

To determine the validity of the model, model predictions were compared to experimental data for two different growth conditions: aerobic growth on acetate plus glucose with a doubling time of $70 \mathrm{~min}$ and aerobic growth on acetate with a doubling time of 145 min (Walsh and Koshland, 1985b). The experimental flux measurements from Walsh and Koshland (1985b) were originally in units of 

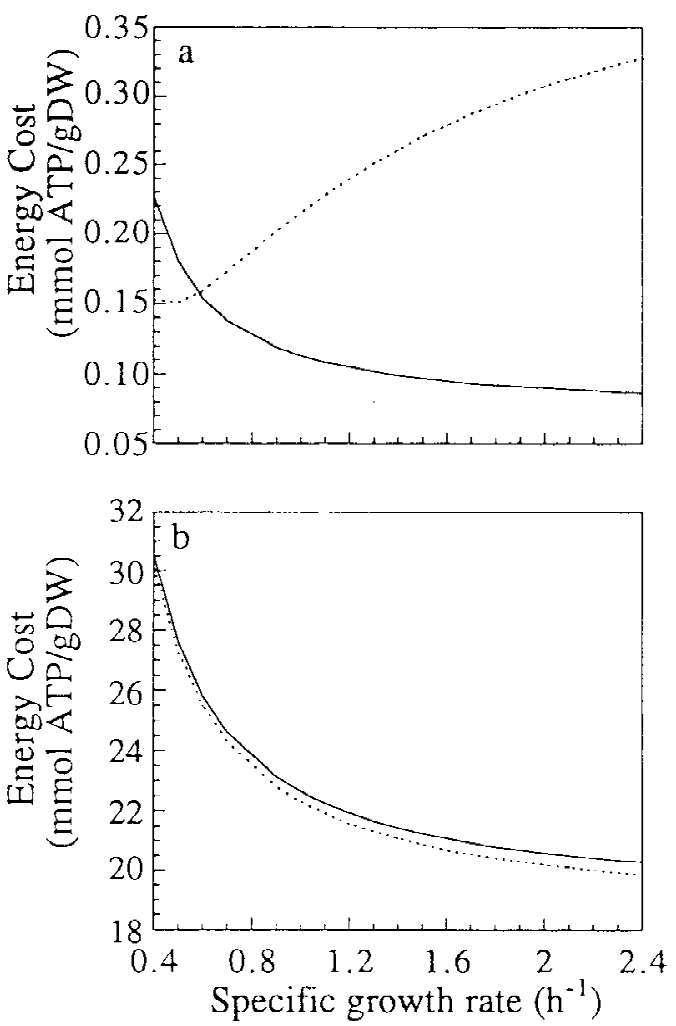

Figure 2. Growth rate dependence of energy requirements. (a) RNA and DNA polymerization energy requirements (Neidhardt et al., 1990). (---) RNA, (-) DNA. (b) Total energy and protein polymerization requirements (Neidhardt et al., 1990). (---) Protein polymerization requirements. (-) Total energy requirements.

millimoles of substrate consumed per minute per liter of cytoplasmic volume. The experimental data was converted to units of millimoles of substrate consumed per hour per gram DW, assuming that cytoplasmic volume of a cell is $75 \%$ of the total volume, and the correlations for cell mass and cell volume (Table VI) were used to convert from a volume basis flux to a gram DW basis flux. The lower bound for the carbon dioxide secretion rate was set at the experimentally determined value, and the values predicted for oxygen uptake rates were in the range of experimental values (Andersen and von Meyenburg, 1980; Harrison and Loveless, 1971; Hempfling and Mainzer, 1975; Marr, 1991; Schulze and Lipe, 1964). The constraints and objective function for each case are presented in Table VII.

For aerobic growth on acetate plus glucose, the model predictions were very similar to experimental data for fluxes through the reactions of glycolysis and the TCA cycle (Fig. 3 ). The experimental glucose uptake rate for this case (7 mmol glucose/g DW h) for a doubling time of 70 min was taken from Herbert and Kornberg (1976), Schulze and Lipe (1964), and Tempest and Neijssel (1987). The average difference between the experimental values and the simulation results was $16 \%$. In addition, the model was able to predict several levels of genetic regulation; for example, the glyoxylate shunt was not functional for growth on glucose and the flux through PEP carboxykinase was toward oxaloacetate (Walsh and Koshland, 1985b).
For aerobic growth on acetate only, the model predictions were also very similar to experimentally determined fluxes (Fig. 4). The average difference between the experimental values and the simulation results for this case was $17 \%$. The model was able to predict that the glyoxylate shunt must be active during growth on acetate to generate sufficient precursors for macromolecule synthesis. The model was also able to predict the correct directions for reactions catalyzed by PEP carboxykinase and malic enzyme (Fraenkel, 1996).

The elemental compositions for bacteria were determined experimentally to be $\mathrm{CN}_{0.2} \mathrm{O}_{0.27}, \mathrm{CN}_{0.25} \mathrm{O}_{0.5}$, and $\mathrm{CN}_{0.24} \mathrm{O}_{0.49}$ (Blanch and Clark, 1996; Characklis and Marshall, 1989) and our biomass composition data predicted elemental balances of $\mathrm{CN}_{0.31} \mathrm{O}_{0.2}$ for aerobic growth on acetate plus glucose and $\mathrm{CN}_{0.3} \mathrm{O}_{0.58}$ for aerobic growth on acetate. Because the model only accounts for a proton balance across the cell membrane and there is no accounting of protons in the cell moving between metabolites, it is not possible to calculate an intracellular proton composition necessary for the protons in the elemental composition. The model predictions of $Y_{x / s}\left(\mathrm{~g} \mathrm{~g} \mathrm{~g}^{-1}\right)=0.53$ (neglecting the acetate consumed) or $Y_{x / s}\left(\mathrm{~g} \mathrm{~g}^{-1}\right)=0.52$ (including acetate and assuming that the acetate has half of the carbon value of glucose) compares favorably with the experimentally determined yield coefficient of $Y_{x / s}\left(\mathrm{~g} \mathrm{~g}^{-1}\right)=0.53$ (Characklis and Marshall, 1989). If the acetate and glucose consumed are normalized per carbon, the model predicts $Y_{x / s}[\mathrm{~g}(\mathrm{~g}$ carbon $\left.)^{-1}\right]=0.086$ compared to experimental data of $Y_{x / s}[\mathrm{~g}(\mathrm{~g}$ carbon $\left.)^{-1}\right]=0.088$ (Characklis and Marshall, 1989). The oxygen uptake rate for a 70-min doubling time was reported as $11-33 \mathrm{mmol}$ of $\mathrm{O}_{2} / \mathrm{g}$ DW $\mathrm{h}$ and the model predicted a flux of $12.6 \mathrm{mmol}$ of $\mathrm{O}_{2} / \mathrm{g}$ DW h. For a 145 -min doubling time the oxygen uptake was reported as $8-29 \mathrm{mmol}$ of $\mathrm{O}_{2} / \mathrm{g}$ DW h (Andersen and von Meyenburg, 1980; Harrison and Loveless, 1971; Hempfling and Mainzer, 1975; Marr, 1991; Schulze and Lipe, 1964) and the model predicted a flux of $16 \mathrm{mmol}$ of $\mathrm{O}_{2} / \mathrm{g}$ DW $\mathrm{h}$. It was observed experimentally that the oxygen consumption rate decreases by $22 \%$ for growth on acetate plus glucose relative to growth on only acetate, even though the growth rate increases (Walsh and Koshland, 1985a), and the model predicted a $21 \%$ decrease in oxygen consumption.

Anaerobic growth on glucose with a 70-min doubling time was simulated to determine if the TCA cycle would branch as observed experimentally (Fig. 5) (Cronan and LaPorte, 1996; Nimmo, 1987). The glucose uptake rate was set to 3 times the aerobic rate (Smith and Neidhardt, 1983), and secretion rates for organic acids were set to experimentally determined values (Tempest and Neijssel, 1987). The model predicted the experimental observation that the TCA cycle is not a cycle but rather branches into a reductive pathway that produces succinyl-CoA and an oxidative pathway that produces $\alpha$-ketoglutarate (Cronan and LaPorte, 1996). The model was also able to predict that $\alpha$-ketoglutarate dehydrogenase is not expressed and that the glyoxylate shunt is closed during anaerobic growth. Unfortunately, there were no available experimental data to validate the flux values. 
Table VII. Simulation parameters: Constraints on fluxes and criteria for maximization and minimization.

\begin{tabular}{|c|c|c|c|c|}
\hline Growth condition & $\begin{array}{r}\text { Lower } \\
\text { bound } \\
(\mathrm{mm}\end{array}$ & $\begin{array}{l}\text { Upper } \\
\text { bound } \\
\text { W h) }\end{array}$ & $\begin{array}{c}\text { Objective } \\
\text { function criterion }\end{array}$ & Note \\
\hline \multicolumn{5}{|l|}{ Aerobic, glucose + acetate } \\
\hline Glucose uptake & 0 & 7 & Maximize & Measured $^{\mathrm{a}}$ \\
\hline Acetate uptake & 0 & 11.94 & Maximize & Measured $^{\mathrm{b}}$ \\
\hline Carbon dioxide secretion & 14 & $\infty$ & Minimize & \\
\hline Acetate secretion & 0 & 11.14 & Maximize & Measured $^{\mathrm{b}}$ \\
\hline Precursor production rate & \multicolumn{2}{|c|}{$\mu$ dependent } & Maximize & Calculated $^{\mathrm{c}}$ \\
\hline \multicolumn{5}{|l|}{ Aerobic, acetate } \\
\hline Acetate uptake & 0 & 33.42 & Maximize & Uptake $^{\mathrm{d}}$ \\
\hline Carbon dioxide secretion & 45 & $\infty$ & Minimize & Measured $^{\mathrm{b}}$ \\
\hline Precursor production rate & \multicolumn{2}{|c|}{$\mu$ dependent } & Maximize & Calculated $^{\mathrm{c}}$ \\
\hline \multicolumn{5}{|l|}{ Anaerobic, glucose } \\
\hline Glucose uptake & 0 & 21 & Maximize & Measured $^{\mathrm{e}}$ \\
\hline Oxygen uptake & 0 & 0 & & \\
\hline Carbon dioxide secretion & 18.48 & $\infty$ & Minimize & Measured $^{\mathrm{f}}$ \\
\hline Acetate secretion & 0 & 7.67 & Maximize & Measured $^{\mathrm{e}}$ \\
\hline Lactate secretion & 0 & 16.69 & Maximize & Measured $^{\mathrm{e}}$ \\
\hline Formate secretion & 0 & 0.50 & Maximize & Measured $^{\mathrm{e}}$ \\
\hline Succinate secretion & 0 & 2.25 & Maximize & Measured $^{\mathrm{e}}$ \\
\hline Ethanol secretion & 0 & 10.46 & Maximize & Measured $^{\mathrm{e}}$ \\
\hline Precursor production rate & \multicolumn{2}{|c|}{$\mu$ dependent } & Maximize & Calculated $^{\mathrm{c}}$ \\
\hline
\end{tabular}

${ }^{a}$ The values present in the literature are in the same range as the value used as a lower bound for the simulation (Herbert and Kornberg, 1976; Schulze and Lipe, 1964; Tempest and Neijssel, 1987).

${ }^{b}$ Data from Walsh and Koshland (1985b).

${ }^{\mathrm{c} C}$ Calculated from correlations in Table VI and information presented in Tables I-V.

${ }^{\mathrm{d}}$ The acetate uptake rate from Walsh and Koshland (1985b) was $41.4 \mathrm{mmol} / \mathrm{g} \mathrm{DW} \mathrm{h}$ but the model predicted an acetate uptake rate of $33.42 \mathrm{mmol} / \mathrm{g} \mathrm{DW} \mathrm{h}$. Any amount of acetate provided in surplus resulted in acetate secretion.

${ }^{\mathrm{e}}$ Data from Smith and Neidhardt (1983).

${ }^{\mathrm{f}}$ Data from Bock and Sawers, (1996).

\section{Sensitivity to Biomass Composition}

To determine the sensitivity of the solutions to the biomass composition, the three cases described above were simulated for incorrect biomass compositions: the cell composition corresponding to a 145-min doubling time (rather than the experimentally determined 70-min doubling time) was used to solve for the fluxes for aerobic growth on glucose and acetate and for anaerobic growth on glucose, and the cell composition corresponding to a 70-min doubling time (rather than the experimentally determined 145min doubling time) was used to solve for the fluxes for aerobic growth on acetate. The constraints and objective functions remained unchanged. For growth on glucose plus acetate, the correct biomass composition gave rise to an average error of $16 \%$ between the experimental data and model predictions for fluxes through the TCA cycle and glycolytic pathway, whereas the incorrect biomass composition increased the average error to $80 \%$. Similarly, for growth on only acetate the correct biomass composition gave rise to an average error of $17 \%$, whereas the incorrect biomass composition increased the average error to $32 \%$.

The results for the two aerobic cases were significantly affected by changing the biomass compositions (Table
VIII). The flux distribution predicted by the model for aerobic growth on acetate with the incorrect biomass composition resulted in no flux through PEP carboxykinase, contrary to experimental observations (Walsh and Koshland, 1985b). For anaerobic growth on glucose, the incorrect biomass composition gave rise to incorrect branching of the TCA cycle with fumarase and malate dehydrogenase catalyzing reactions in directions that were not observed experimentally (Cronan and LaPorte, 1996). Further, the simulation suggested that there would be flux through the glyoxylate shunt, which was not observed experimentally (Nimmo, 1987). The sensitivity analysis of the anaerobic case was not performed because there were no available experimental data for comparisons.

\section{Sensitivity Analysis on Flux Constraints}

Sensitivity analysis was performed on the three cases to determine which reactions were the most constrained; that is, which reactions had the least amount of flexibility in flux values for which the solution will not change. The flexibility in the flux for a reaction is the range of flux values (represented as a percentage) that can occur without changing the basis matrix (Figs. 3-5). 


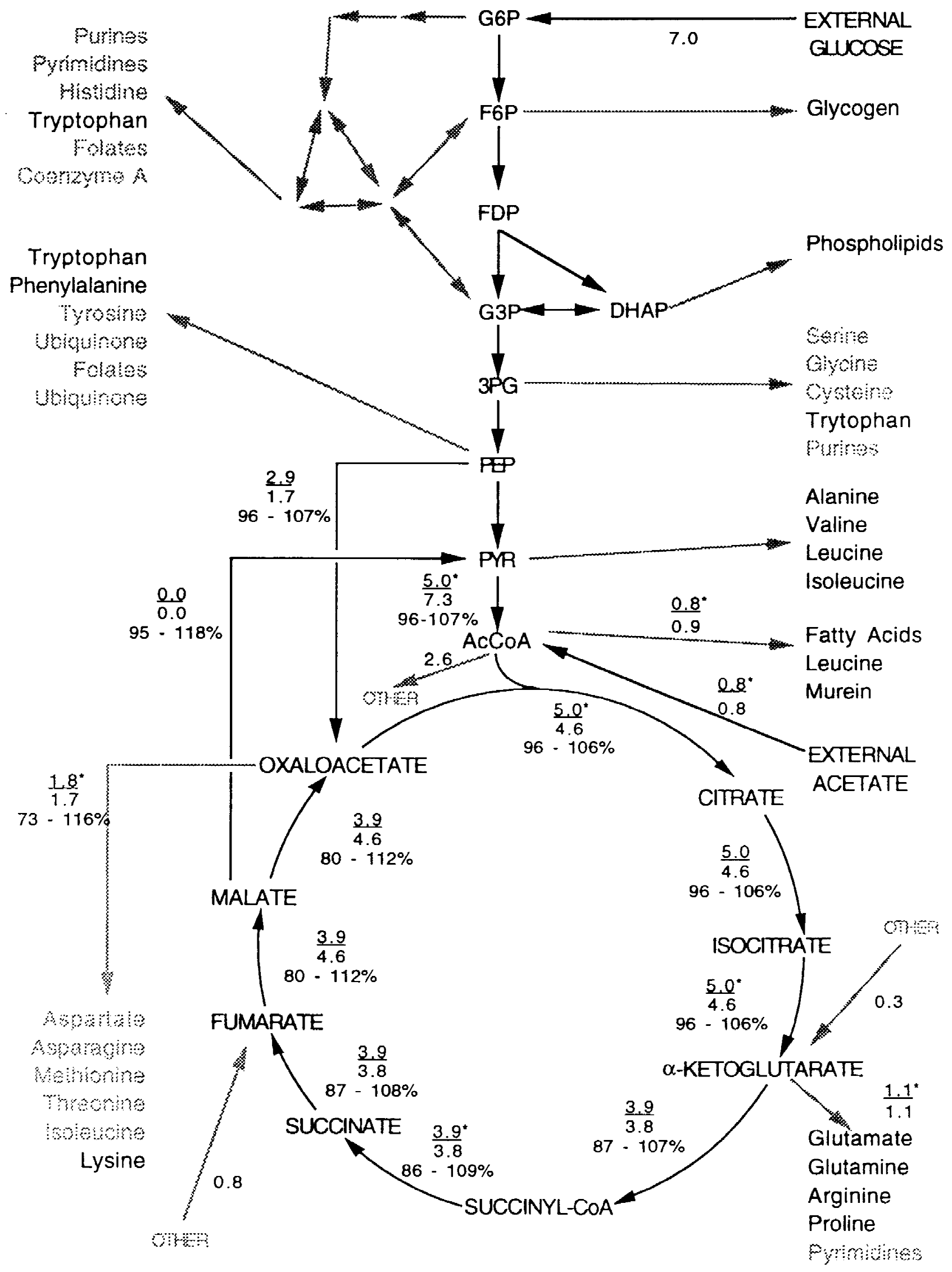

Figure 3. Fluxes through glycolysis and TCA cycle during aerobic growth on glucose plus acetate. The doubling time was 70 min. Experimental data are underlined (Walsh and Koshland, 1985b), the simulation results are the center values, and the flexibility of the reactions (as a percent of the simulation results) are on the bottom. Solid lines and words indicate highly constrained reactions and precursors. Stippled lines and words indicate less constrained reactions and precursors. The flux values measured experimentally are marked with an asterisk, and the flux values calculated from the experimental data using a simpler model are unmarked (Walsh and Koshland, 1985b). The "other" on the figure means synthesis of the metabolite due to the presence of other enzymes not depicted in the figure. 


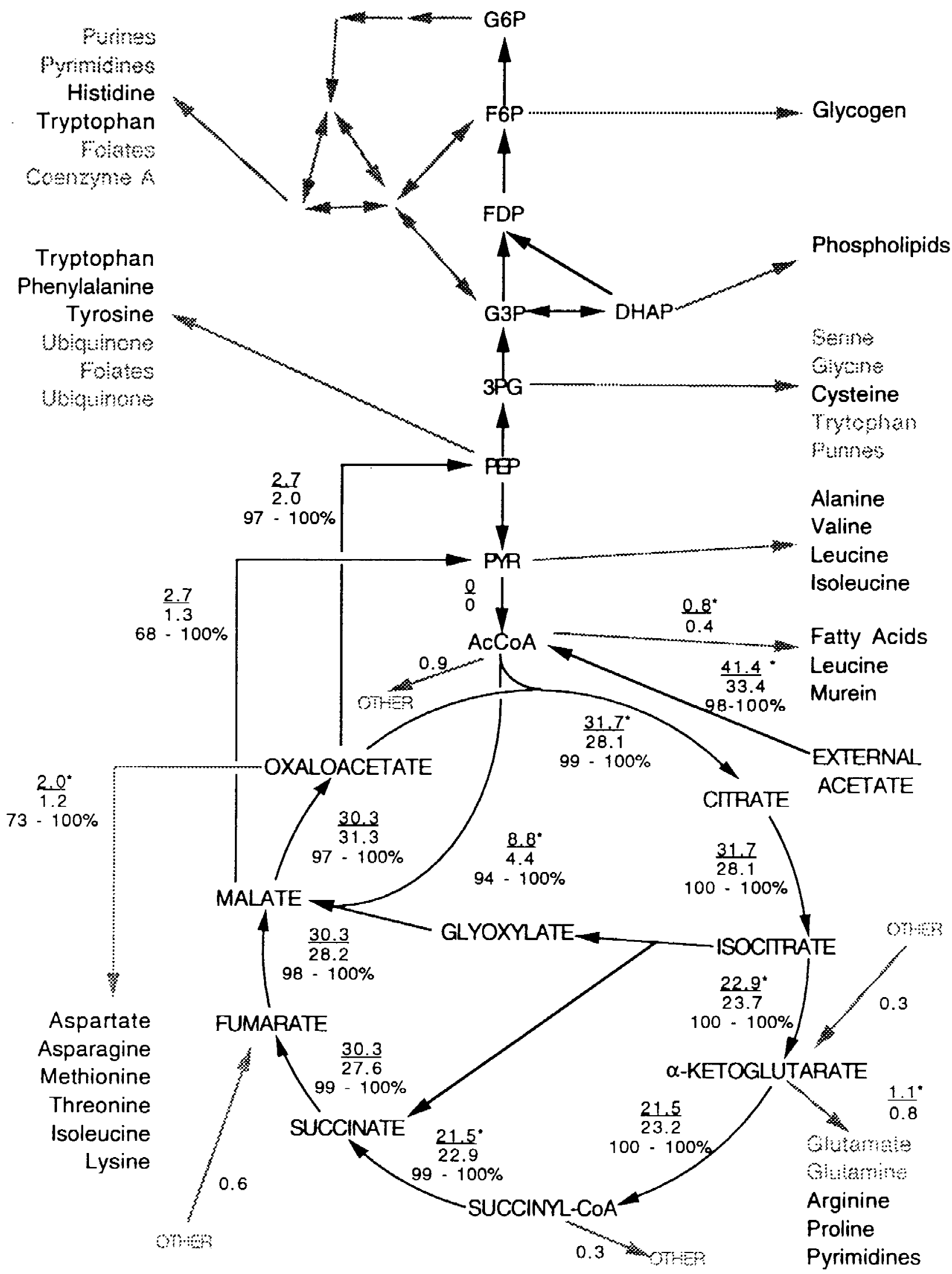

Figure 4. Fluxes through glycolysis and TCA cycle during aerobic growth on acetate. The doubling time was 145 min. Experimental data are underlined (Walsh and Koshland, 1985b), the simulation results are the center values, and the flexibility of the reactions (as a percent of the simulation results) are on the bottom. Solid lines and words indicate highly constrained reactions and precursors. Stippled lines and words indicate less constrained reactions and precursors. The flux values experimentally measured are marked with an asterisk, and the flux values calculated from the experimental data using a simpler model are unmarked (Walsh and Koshland, 1985b). The "other" on the figure means synthesis of the metabolite due to the presence of other enzymes not depicted in the figure. 
Table VIII. Effect of biomass composition on the simulation results. The simulation results for fluxes through key reactions of TCA cycle and glycolysis for two different biomass compositions are compared to experimental data. The error is relative to experimental data (Walsh and Koshland, 1985b). Only the flux values presented in Table 8 were used to determine average error percentages.

\begin{tabular}{|c|c|c|c|c|c|c|}
\hline & \multicolumn{3}{|c|}{ Aerobic, glucose + acetate } & \multicolumn{3}{|c|}{ Aerobic acetate } \\
\hline & \multicolumn{2}{|c|}{ Predictions } & \multirow{2}{*}{$\frac{\text { Experiment }^{\mathrm{a}}}{\tau_{D}=70}$} & \multicolumn{2}{|c|}{ Predictions } & \multirow{2}{*}{$\frac{\text { Experiment }^{\mathrm{a}}}{\tau_{D}=145}$} \\
\hline & $\tau_{D}=70$ & $\tau_{D}=145$ & & $\tau_{D}=70$ & $\tau_{D}=145$ & \\
\hline $\begin{array}{l}\text { PEP } \\
\quad \text { carboxykinase }\end{array}$ & 0 & 0 & 0 & $\begin{array}{c}0 \\
(100 \%)\end{array}$ & $\begin{array}{c}2.0 \\
(28 \%)\end{array}$ & 2.71 \\
\hline PEP carboxylase & $\begin{array}{c}1.7 \\
(41 \%)\end{array}$ & $\begin{array}{c}0.8 \\
(71 \%)\end{array}$ & 2.9 & 0 & 0 & 0 \\
\hline $\begin{array}{l}\text { Pyruvate } \\
\text { dehydrogenase }\end{array}$ & $\begin{array}{c}7.3 \\
(45 \%)\end{array}$ & $\begin{array}{c}7.5 \\
(50 \%)\end{array}$ & 5.0 & 0 & 0 & 0 \\
\hline Citrate synthase & $\begin{array}{l}4.6 \\
(8 \%)\end{array}$ & $\begin{array}{c}1.0 \\
(79 \%)\end{array}$ & 5.0 & $\begin{array}{c}25.1 \\
(21 \%)\end{array}$ & $\begin{array}{c}28.1 \\
(11 \%)\end{array}$ & 31.7 \\
\hline Aconitase & $\begin{array}{c}4.6 \\
(8 \%)\end{array}$ & $\begin{array}{c}1.0 \\
(79 \%)\end{array}$ & 5.0 & $\begin{array}{c}25.1 \\
(21 \%)\end{array}$ & $\begin{array}{c}28.1 \\
(11 \%)\end{array}$ & 31.7 \\
\hline $\begin{array}{l}\text { Isocitrate } \\
\text { dehydrogenase }\end{array}$ & $\begin{array}{c}4.6 \\
(8 \%)\end{array}$ & $\begin{array}{c}0.6 \\
(87 \%)\end{array}$ & 5.0 & $\begin{array}{c}18.5 \\
(19 \%)\end{array}$ & $\begin{array}{l}23.7 \\
(3 \%)\end{array}$ & 22.9 \\
\hline $\begin{array}{l}\text { 2-Ketoglutarate } \\
\text { dehydrogenase }\end{array}$ & $\begin{array}{l}3.8 \\
(3 \%)\end{array}$ & $\begin{array}{c}0 \\
(100 \%)\end{array}$ & 3.87 & $\begin{array}{c}17.7 \\
(18 \%)\end{array}$ & $\begin{array}{l}23.2 \\
(8 \%)\end{array}$ & 21.5 \\
\hline $\begin{array}{l}\text { Succinate } \\
\text { thiokinase }\end{array}$ & $\begin{array}{c}3.8 \\
(3 \%)\end{array}$ & $\begin{array}{c}0 \\
(100 \%)\end{array}$ & 3.9 & $\begin{array}{c}17.2 \\
(20 \%)\end{array}$ & $\begin{array}{l}22.9 \\
(7 \%)\end{array}$ & 21.5 \\
\hline $\begin{array}{l}\text { Succinate } \\
\text { dehydrogenase }\end{array}$ & $\begin{array}{l}3.8 \\
(3 \%)\end{array}$ & $\begin{array}{c}0.4 \\
(90 \%)\end{array}$ & 3.9 & $\begin{array}{c}24.3 \\
(20 \%)\end{array}$ & $\begin{array}{l}27.6 \\
(9 \%)\end{array}$ & 30.3 \\
\hline Fumarase & $\begin{array}{c}4.6 \\
(20 \%)\end{array}$ & $\begin{array}{c}1.1 \\
(72 \%)\end{array}$ & 39 & $\begin{array}{c}25.2 \\
(17 \%)\end{array}$ & $\begin{array}{l}28.2 \\
(7 \%)\end{array}$ & 30.3 \\
\hline $\begin{array}{l}\text { Malate } \\
\text { dehydrogenase }\end{array}$ & $\begin{array}{c}4.6 \\
(20 \%)\end{array}$ & $\begin{array}{c}1.1 \\
(72 \%)\end{array}$ & 3.87 & $\begin{array}{c}26.9 \\
(11 \%)\end{array}$ & $\begin{array}{l}31.3 \\
(3 \%)\end{array}$ & 30.3 \\
\hline Malic enzyme & 0 & 0 & 0 & $\begin{array}{c}4.9 \\
(80 \%)\end{array}$ & $\begin{array}{c}1.3 \\
(52 \%)\end{array}$ & 2.7 \\
\hline Isocitrate lyase & 0 & 0.4 & 0 & $\begin{array}{c}6.6 \\
(25 \%)\end{array}$ & $\begin{array}{c}4.4 \\
(50 \%)\end{array}$ & 8.8 \\
\hline Overall error ${ }^{\mathrm{b}}$ & $16 \%$ & $80 \%$ & & $32 \%$ & $17 \%$ & \\
\hline
\end{tabular}

aData from Walsh and Koshland (1985b).

${ }^{\mathrm{b}}$ The error is calculated as (|experiment - prediction|)/experiment.

In general, the sensitivity analysis indicated that glycolysis was the most constrained pathway during aerobic and anaerobic growth on glucose, whereas the TCA cycle was the most constrained pathway during growth on acetate (Table IX). The rigid constraints on glycolysis during growth on glucose are due, in part, to the sensitivity of the leucine and valine biosynthetic pathways, which diverge from pyruvate. For growth on acetate, the rigid constraints on the TCA cycle are partly due to the rigidity in isocitrate dehydrogenase and in the cysteine and methionine synthesis rates. In the anaerobic case, the TCA cycle reactions had a lower bound of $59 \%$ of the flux value and no upper bound except for reactions catalyzed by fumarase and malate dehydrogenase, which had bounds of 92-142\%; these are the two enzymes responsible for the TCA cycle branching under anaerobic growth conditions by changing direction of the reactions.

\section{DISCUSSION}

A steady-state, flux-based model was developed to study the distribution of mass and energy fluxes through the $E$. coli metabolic reaction network. The contributions of this model are threefold: a relatively complete data base of reactions from glucose to precursors, coenzymes, and prosthetic groups was used; correlations for experimentally observed changes in biomass composition with growth rate were included; and energy requirements for growth were based on mechanistic requirements rather than on a lumped maintenance energy requirement.

The model incorporated 153 reversible and 147 irreversible reactions using 289 metabolites. The relatively complete nature of the reactions will allow one to examine the effect of mutations in specific genes on fluxes through pathways by constraining fluxes through relevant enzymes. It will also allow more flexibility in choosing which metabolites or pathways might be most amenable to alterations to engineer metabolism. In genetically manipulating cells for the production of a desired compound or protein, the growth rate of the cell may change significantly. Therefore, incorporation of growth-rate dependent biomass composition as well as energy requirements in such a model would allow one to accurately simulate the effect of the growth rate changes on the distribution of resources throughout the cell. 


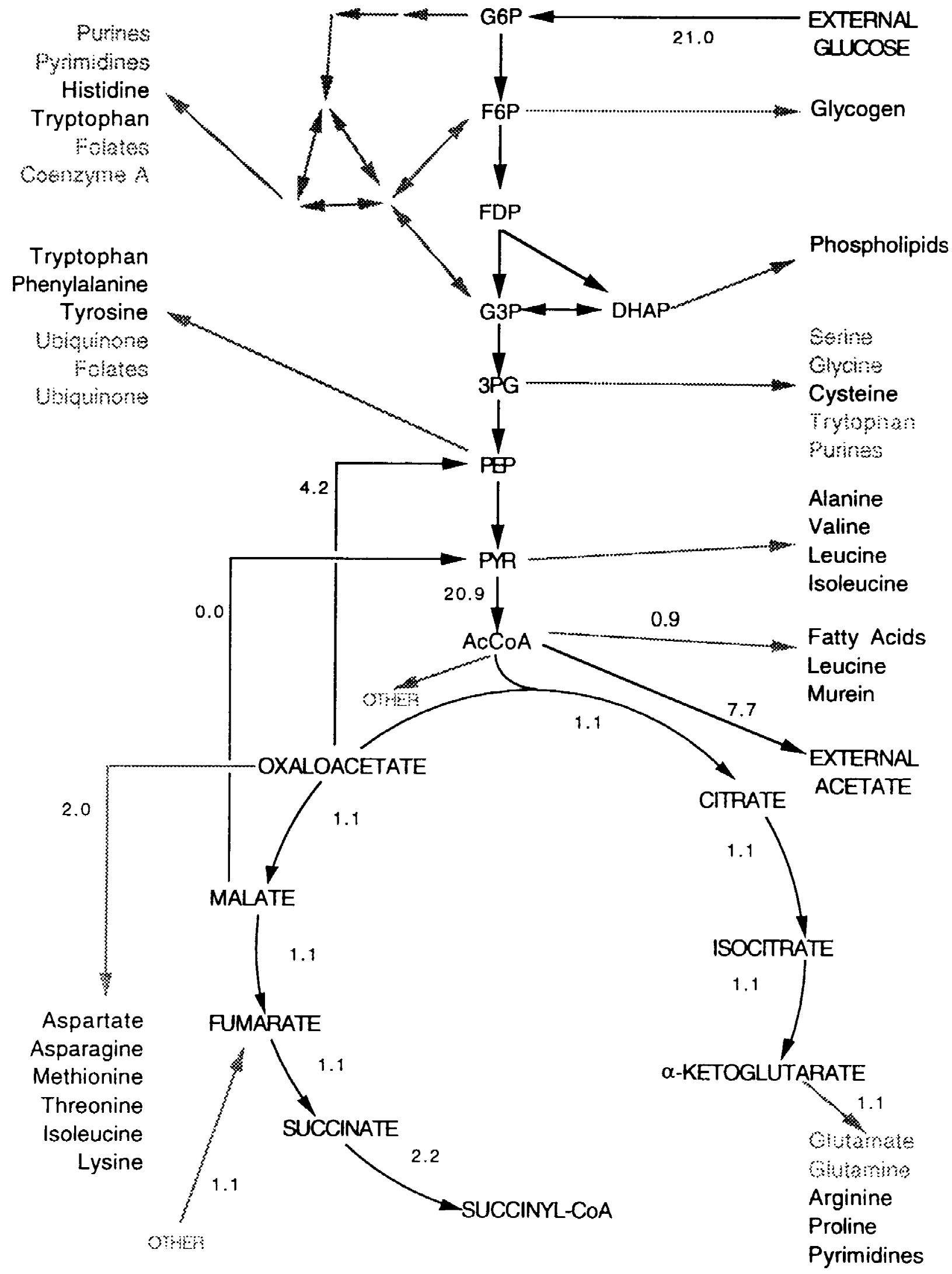

Figure 5. Fluxes through glycolysis and TCA cycle during anaerobic growth on glucose. The doubling time was 70 min. Solid lines and words indicate highly constrained reactions and precursors. Stippled lines and words indicate less constrained reactions and precursors. The "other"' on the figure means synthesis of the metabolite due to the presence of other enzymes not depicted in the figure. 
Experimental data were used to develop correlations for biomass composition at different growth rates. The biomass sensitivity analysis indicates the importance of incorporating changes in biomass composition with growth rate. For growth on acetate plus glucose, the biomass composition greatly affected the fluxes. Using the correct composition, the predicted fluxes differed from experimental measurements by $16 \%$. Using an incorrect composition, the predicted fluxes differed from experimental measurements by $80 \%$. For growth on acetate the predicted fluxes using a correct composition differed from experimental measurements by $17 \%$, and for the incorrect composition the predicted fluxes differed from experimental measurements by $32 \%$.

Maintenance energy terms have often been incorporated into models to balance energy requirements that could not be accounted for through biomass synthesis requirements (Pirt, 1965, 1982). However, the use of the maintenance energy term does not account mechanistically for this energy drain. To improve the predictive power of stoichiometric models, we accounted for the energy drain using a mechanistic approach and correlated this with growth rate. Besides incorporating the obvious energy requirements, such as those for polymerization of biopolymers, we also incorporated energy requirements, such as those for proofreading of DNA and protein, RNA processing, and proton leakage across membranes. Because the composition of the cell changes with growth rate, the energy requirements were scaled with cell composition. In a similar manner, proton leakage was scaled with the cell's surface area, which increases with growth rate.

There was close agreement between the predicted and experimentally determined flux values, and the solutions agreed with observed regulation under the different growth conditions. The model was able to predict the opening and closing of the glyoxylate shunt in the presence and absence of acetate as the sole carbon source. The $\mathrm{O}_{2}$ uptake rate under aerobic growth conditions predicted by the model agreed with experimental data (Andersen and von Meyenburg, 1980; Harrison and Loveless, 1971; Hempfling and
Mainzer, 1975; Marr, 1991; Schulze and Lipe, 1964). The model also predicted the branching of the TCA cycle with no flux through $\alpha$-ketoglutarate dehydrogenase under anaerobic growth conditions. The largest errors occurred at the branch points of glycolysis and the TCA cycle, where there were drains for the synthesis of cellular constituents. Because the data used to develop the correlations for the biomass components came from many different experiments conducted under various growth conditions using various strains of $E$. coli, differences in biomass composition could be responsible for these discrepancies. A more complete set of experimental data is required to improve model predictions.

Sensitivity analysis was also performed to determine how changes in the fluxes would affect the basis matrix that was used to arrive at a given solution. This type of analysis indicates how much the flux through a given reaction can change and still allow the model to arrive at the optimal solution using the same basis matrix. This analysis indicates that during growth on glucose the reactions of glycolysis are the most constrained, with the TCA cycle and the pentose phosphate shunt reactions close behind. In contrast, the reactions of the TCA cycle are the most highly constrained during growth on acetate. Because the glycolysis and the TCA cycle reactions are involved in both energy and precursor production, one would expect them to be the most highly constrained reactions.

This metabolic model should be a useful tool for studying the effects of reengineering pathways. It can provide information about how the overall flux distribution will be affected if an organism is forced to synthesize a product or to degrade a pollutant. The model can also elucidate cases under which it will not be possible to satisfy growth demands and secrete a product of interest at a desired level. The sensitivity analysis can be used to study the stiffness of the solutions and the regions where bottlenecks may form under certain growth conditions. The model shows a high degree of sensitivity to the biomass information, and therefore the dependence of biomass composition on growth rates is an important aspect of a flux-based metabolic model.

Table IX. Sensitivity analysis of basis matrix with respect to flux constraints.

\begin{tabular}{|c|c|c|c|}
\hline \multirow[b]{2}{*}{ Pathway/enzyme } & \multicolumn{3}{|c|}{ Allowable fluxes ${ }^{\mathrm{a}}$ (\% solution value) } \\
\hline & Glucose + acetate, aerobic & Acetate, aerobic & Glucose, anaerobic \\
\hline Glycolysis & $94-103$ & $84-100$ & $100-101$ \\
\hline Pentose phosphate & $95-109$ & $81-100$ & 94-101 \\
\hline TCA cycle & $90-106$ & $100-100$ & $92-142$ \\
\hline Carbon dioxide secretion & $68-108$ & $50-100$ & $72-106$ \\
\hline Ammonia uptake & $85-109$ & $85-100$ & $87-103$ \\
\hline Oxygen uptake & $87-108$ & $96-100$ & \\
\hline Acetate secretion & $48-116$ & & $46-117$ \\
\hline Precursors tightly constrained & $\begin{array}{l}\text { Phosphatidylethanolamine } \\
\text { Arginine } \\
\text { Lysine } \\
\text { Leucine } \\
\text { Valine }\end{array}$ & $\begin{array}{l}\text { Phosphatidylethanolamine } \\
\text { Cardiolipin } \\
\text { Cysteine } \\
\text { Methionine }\end{array}$ & Phosphatidylethanolamine \\
\hline
\end{tabular}

\footnotetext{
${ }^{a}$ Values refer to the amount the flux value can change without changing the basis matrix. The most tightly bounded reaction in a particular pathway determines the bounds on that pathway.
} 
APPENDIX A: METABOLIC PATHWAYS IN STOICHIOMETRIC MATRIX

GENE NAMES ARE SUPPLIED WHERE POSSIBLE.

\begin{tabular}{|c|c|c|c|}
\hline Enzyme & Gene & Pathway & Reference \\
\hline \multicolumn{4}{|l|}{ Glycolysis } \\
\hline Phosphotransferase system & ptsI, ptsH & $\mathrm{GLC}+\mathrm{PEP} \rightarrow \mathrm{PYR}+\mathrm{G} 6 \mathrm{P}$ & Fraenkel, 1996; Postma et al., 1996 \\
\hline Phosphoglucose isomerase & $p g i$ & G6P $\leftrightarrow$ F6P & Fraenkel, 1996 \\
\hline Phosphofructokinase & $p f k$ & $\mathrm{~F} 6 \mathrm{P}+\mathrm{ATP} \leftrightarrow \mathrm{ADP}+\mathrm{F} 16 \mathrm{P}$ & Fraenkel, 1996 \\
\hline Fructose-1,6-bisphosphate aldolase & $f b p$ & $\mathrm{~F} 16 \mathrm{P}+\mathrm{PI} \rightarrow \mathrm{F} 6 \mathrm{P}$ & Fraenkel, 1996 \\
\hline Fructose-1,6-bisphosphatase & $f b a$ & $\mathrm{~F} 16 \mathrm{P} \leftrightarrow \mathrm{T} 3 \mathrm{P} 1+\mathrm{T} 3 \mathrm{P} 2$ & Fraenkel, 1996 \\
\hline Triosphosphate isomerase & tpi & $\mathrm{T} 3 \mathrm{P} 1 \leftrightarrow \mathrm{T} 3 \mathrm{P} 2$ & Fraenkel, 1996 \\
\hline $\begin{array}{l}\text { Glyceraldehyde-3-phosphate } \\
\text { dehydrogenase }\end{array}$ & gap & $\mathrm{T} 3 \mathrm{P} 1+\mathrm{PI}+\mathrm{NAD} \leftrightarrow \mathrm{NADH}+13 \mathrm{P} 2 \mathrm{DG}$ & Fraenkel, 1996 \\
\hline Phosphoglycerate kinase & $p g k$ & $13 \mathrm{P} 2 \mathrm{DG}+\mathrm{ADP} \leftrightarrow \mathrm{ATP}+3 \mathrm{PDGL}$ & Fraenkel, 1996 \\
\hline Phosphoglycerate mutase & gpm & $3 \mathrm{PDGL} \leftrightarrow 2 \mathrm{PDGL}$ & Fraenkel, 1996 \\
\hline Enolase & eno & $2 \mathrm{PDGL} \leftrightarrow \mathrm{PEP}$ & Fraenkel, 1996 \\
\hline Pyruvate kinase & pyk & $\mathrm{PEP}+\mathrm{ADP} \rightarrow \mathrm{ATP}+\mathrm{PYR}$ & Fraenkel, 1996 \\
\hline PEP carboxykinase & pck & $\mathrm{OA}+\mathrm{ATP} \leftrightarrow \mathrm{PEP}+\mathrm{CO} 2+\mathrm{ADP}$ & Fraenkel, 1996 \\
\hline PEP carboxylase & $p p c$ & $\mathrm{PEP}+\mathrm{CO} 2 \rightarrow \mathrm{OA}+\mathrm{PI}$ & Fraenkel, 1996 \\
\hline Pyruvate dehydrogenase & $p d h$ & $\mathrm{PYR}+\mathrm{COA}+\mathrm{NAD} \rightarrow \mathrm{NADH}+\mathrm{CO} 2+\mathrm{ACCOA}$ & Fraenkel, 1996 \\
\hline PEP synthase & pps & $\mathrm{PYR}+\mathrm{ATP} \rightarrow \mathrm{PEP}+\mathrm{AMP}+\mathrm{PI}$ & Fraenkel, 1996 \\
\hline \multicolumn{4}{|l|}{ Pentose phosphate shunt } \\
\hline Glucose-6-phosphate dehydrogenase & $z w f$ & G6P + NADP $\leftrightarrow$ D6PGL + NADPH & Fraenkel, 1996 \\
\hline 6-Phosphogluconolactonase & $p g l$ & D6PGL $\rightarrow$ D6PGC & Fraenkel, 1996 \\
\hline 6-Phosphogluconate dehydrogenase & gnd & $\mathrm{D} 6 \mathrm{PGC}+\mathrm{NADP} \leftrightarrow \mathrm{NADPH}+\mathrm{CO} 2+\mathrm{RL} 5 \mathrm{P}$ & Fraenkel, 1996 \\
\hline Ribose-5-phosphate isomerase & $r p i$ & RL5P $\leftrightarrow$ R5P & Fraenkel, 1996 \\
\hline Ribose-5-phosphate epimerase & rpe & $\mathrm{RL} 5 \mathrm{P} \leftrightarrow \mathrm{X} 5 \mathrm{P}$ & Fraenkel, 1996 \\
\hline Transketolase 1 & $t k t A$ & $\mathrm{R} 5 \mathrm{P}+\mathrm{X} 5 \mathrm{P} \leftrightarrow \mathrm{T} 3 \mathrm{P} 1+\mathrm{S} 7 \mathrm{P}$ & Fraenkel, 1996 \\
\hline Transaldolase & tal & $\mathrm{T} 3 \mathrm{P} 1+\mathrm{S} 7 \mathrm{P} \leftrightarrow \mathrm{E} 4 \mathrm{P}+\mathrm{F} 6 \mathrm{P}$ & Fraenkel, 1996 \\
\hline Transketolase 2 & $t k t B$ & $\mathrm{X} 5 \mathrm{P}+\mathrm{E} 4 \mathrm{P} \leftrightarrow \mathrm{F} 6 \mathrm{P}+\mathrm{T} 3 \mathrm{P} 1$ & Fraenkel, 1996 \\
\hline 6-Phosphogluconate dehydrase & $e d d$ & D6PGC $\rightarrow$ 2K3D6PG & Fraenkel, 1996 \\
\hline $\begin{array}{l}\text { 2-Keto-3-deoxy-6-phospho- } \\
\text { gluconate aldolase }\end{array}$ & $e d a$ & $2 \mathrm{~K} 3 \mathrm{D} 6 \mathrm{PG} \rightarrow \mathrm{T} 3 \mathrm{P} 1+\mathrm{PYR}$ & Fraenkel, 1996 \\
\hline \multicolumn{4}{|l|}{ Glycogen metabolism } \\
\hline Phosphogluconomutase & pgm & G6P $\leftrightarrow$ G1P & Fraenkel, 1996 \\
\hline Glycogen synthase & $\operatorname{glg} A$ & $\mathrm{G} 1 \mathrm{P}+\mathrm{ATP} \rightarrow \mathrm{ADP}+\mathrm{PPI}+\mathrm{GLYCOGEN}$ & Preiss, 1996 \\
\hline Glycogen phosphorylase & $\operatorname{glg} P$ & GLYCOGEN + PI $\rightarrow$ G1P & Preiss, 1996 \\
\hline \multicolumn{4}{|l|}{ Dissimilation of pyruvate } \\
\hline Lactate dehydrogenase & $l d h$ & $\mathrm{PYR}+\mathrm{NADH} \leftrightarrow \mathrm{NAD}+\mathrm{LAC}$ & $\begin{array}{l}\text { Bock and Sawers, 1996; Kessler } \\
\text { and Knappe, } 1996\end{array}$ \\
\hline Alcohol dehydrogenase & $a d h$ & $\mathrm{ACAL}+\mathrm{NADH} \leftrightarrow \mathrm{ETHANOL}+\mathrm{NAD}$ & $\begin{array}{l}\text { Bock and Sawers, 1996; Kessler } \\
\text { and Knappe, } 1996\end{array}$ \\
\hline Acetaldehyde dehydrogenase & $a d h$ & $\mathrm{AC}+\mathrm{NADH} \leftrightarrow \mathrm{NAD}+\mathrm{ACAL}$ & $\begin{array}{l}\text { Bock and Sawers, 1996; Kessler } \\
\text { and Knappe, } 1996\end{array}$ \\
\hline Pyruvate formate lyase & $p f l$ & $\mathrm{PYR}+\mathrm{COA} \rightarrow \mathrm{ACCOA}+\mathrm{FORMATE}$ & $\begin{array}{l}\text { Bock and Sawers, 1996; Kessler } \\
\text { and Knappe, } 1996\end{array}$ \\
\hline Phosphotransacetylase & pta & $\mathrm{ACCOA}+\mathrm{PI} \leftrightarrow \mathrm{ACTP}+\mathrm{COA}$ & $\begin{array}{l}\text { Bock and Sawers, 1996; Kessler } \\
\text { and Knappe, } 1996\end{array}$ \\
\hline Acetate kinase & ackA & $\mathrm{ACTP}+\mathrm{ADP} \leftrightarrow \mathrm{ATP}+\mathrm{AC}$ & $\begin{array}{l}\text { Bock and Sawers, 1996; Kessler } \\
\text { and Knappe, } 1996\end{array}$ \\
\hline Formate hydrogen lyase & $f h l$ & FORMATE $\rightarrow \mathrm{CO} 2$ & $\begin{array}{l}\text { Bock and Sawers, 1996; Kessler } \\
\text { and Knappe, } 1996\end{array}$ \\
\hline \multicolumn{4}{|l|}{ TCA cycle and glyoxylate bypass } \\
\hline Citrate synthase & gltA & $\mathrm{ACCOA}+\mathrm{OA} \leftrightarrow \mathrm{COA}+\mathrm{CIT}$ & Cronan and LaPorte, 1996 \\
\hline Aconitase & acn & $\mathrm{CIT} \leftrightarrow \mathrm{ICIT}$ & Cronan and LaPorte, 1996 \\
\hline Isocitrate dehydrogenase & $i d h$ & $\mathrm{ICIT}+\mathrm{NAD} \leftrightarrow \mathrm{CO} 2+\mathrm{NADH}+\mathrm{AKG}$ & Cronan and LaPorte, 1996 \\
\hline 2-Ketoglutarate dehydrogenase & sucAB & $\mathrm{AKG}+\mathrm{NAD}+\mathrm{COA} \leftrightarrow \mathrm{CO} 2+\mathrm{NADH}+\mathrm{SUCCOA}$ & Cronan and LaPorte, 1996 \\
\hline Succinate thiokinase & sucCD & $\mathrm{SUCCOA}+\mathrm{GDP}+\mathrm{PI} \leftrightarrow \mathrm{GTP}+\mathrm{COA}+\mathrm{SUCC}$ & Cronan and LaPorte, 1996 \\
\hline Succinate dehydrogenase & $s d h A B C D$ & $\mathrm{SUCC}+\mathrm{FAD} \rightarrow \mathrm{FADH} 2+\mathrm{FUM}$ & Cronan and LaPorte, 1996 \\
\hline Fumurate reductase & frdABCD & $\mathrm{FUM}+\mathrm{FADH} 2 \rightarrow \mathrm{SUCC}+\mathrm{FAD}$ & Cronan and LaPorte, 1996 \\
\hline Fumarase & fumAB & FUM $\leftrightarrow$ MAL & Cronan and LaPorte, 1996 \\
\hline Malate dehydrogenase & $m d h$ & $\mathrm{MAL}+\mathrm{NAD} \leftrightarrow \mathrm{NADH}+\mathrm{OA}$ & Cronan and LaPorte, 1996 \\
\hline Malic enzyme & mez & $\mathrm{MAL}+\mathrm{NADP} \rightarrow \mathrm{CO} 2+\mathrm{NADPH}+\mathrm{PYR}$ & Cronan and LaPorte, 1996 \\
\hline Malic enzyme & mez & $\mathrm{MAL}+\mathrm{NAD} \rightarrow \mathrm{CO} 2+\mathrm{NADH}+\mathrm{PYR}$ & Cronan and LaPorte, 1996 \\
\hline
\end{tabular}


APPENDIX A: CONTINUED

\begin{tabular}{|c|c|c|c|}
\hline Enzyme & Gene & Pathway & Reference \\
\hline Isocitrate lyase & aceA & $\mathrm{ICIT} \rightarrow \mathrm{GLX}+\mathrm{SUCC}$ & Cronan and LaPorte, 1996 \\
\hline Malate synthase & $a c e B$ & $\mathrm{ACCOA}+\mathrm{GLX} \rightarrow \mathrm{COA}+\mathrm{MAL}$ & Cronan and LaPorte, 1996 \\
\hline \multicolumn{4}{|l|}{ Respiration } \\
\hline NADH dehydrogenase II & $n d h$ & $\mathrm{NADH}+\mathrm{Q} \rightarrow \mathrm{NAD}+\mathrm{QH} 2$ & Gennis and Stewart, 1996 \\
\hline NADH dehydrogenase I & $n d h$ & $\mathrm{NADH}+\mathrm{Q} \rightarrow \mathrm{NAD}+\mathrm{QH} 2+4 \mathrm{HEXT}$ & Gennis and Stewart, 1996 \\
\hline Formate dehydrogenase & & FORMATE $+\mathrm{Q} \rightarrow 2$ HEXT $+\mathrm{QH} 2+\mathrm{CO} 2$ & Gennis and Stewart, 1996 \\
\hline Cytochrome oxidase bo3 & & $\mathrm{QH} 2+1 / 2 \mathrm{O} 2 \rightarrow \mathrm{Q}+4 \mathrm{HEXT}$ & Gennis and Stewart, 1996 \\
\hline Cytochrome oxidase bd & & $\mathrm{QH} 2+1 / 2 \mathrm{O} 2 \rightarrow \mathrm{Q}+2 \mathrm{HEXT}$ & Gennis and Stewart, 1996 \\
\hline Succinate dehydrogenase complex & & $\mathrm{FADH} 2+\mathrm{Q} \leftrightarrow \mathrm{FAD}+\mathrm{QH} 2$ & Gennis and Stewart, 1996 \\
\hline \multicolumn{4}{|l|}{ ATP synthesis } \\
\hline F0F1-ATPase & unc & $\mathrm{ATP} \leftrightarrow \mathrm{ADP}+\mathrm{PI}+3 \mathrm{HEXT}$ & Harold and Maloney, 1996 \\
\hline \multicolumn{4}{|l|}{ Biosynthesis of aspartate } \\
\hline Aspartate transaminase & $\operatorname{aspC}$ & $\mathrm{OA}+\mathrm{GLU} \leftrightarrow \mathrm{ASP}+\mathrm{AKG}$ & Reitzer, 1996 \\
\hline \multicolumn{4}{|l|}{ Biosynthesis of asparagine } \\
\hline $\begin{array}{l}\text { Glutamine-dependent asparagine } \\
\text { synthetase }\end{array}$ & $\operatorname{asn} B$ & $\mathrm{ASP}+\mathrm{ATP}+\mathrm{GLN} \rightarrow \mathrm{GLU}+\mathrm{ASN}+\mathrm{AMP}+\mathrm{PPI}$ & Reitzer, 1996 \\
\hline $\begin{array}{l}\text { Ammonia-dependent asparagine } \\
\text { synthetase }\end{array}$ & $\operatorname{asn} A$ & $\mathrm{ASP}+\mathrm{ATP}+\mathrm{NH} 3 \rightarrow \mathrm{ASN}+\mathrm{AMP}+\mathrm{PPI}$ & Reitzer, 1996 \\
\hline \multicolumn{4}{|l|}{ Biosynthesis of glutamate } \\
\hline Glutamate dehydrogenase & $g d h A$ & $\mathrm{AKG}+\mathrm{NH} 3+\mathrm{NADPH} \rightarrow \mathrm{GLU}+\mathrm{NADP}$ & Reitzer, 1996 \\
\hline Glutamine synthatase & $g \ln A$ & $\mathrm{GLU}+\mathrm{NH} 3+\mathrm{ATP} \rightarrow \mathrm{GLN}+\mathrm{ADP}+\mathrm{PI}$ & Reitzer, 1996 \\
\hline Glutamate synthase & gltBD & $\mathrm{AKG}+\mathrm{GLN}+\mathrm{NADPH} \rightarrow \mathrm{NADP}+2 \mathrm{GLU}$ & Reitzer, 1996 \\
\hline \multicolumn{4}{|l|}{ Biosynthesis of alanine } \\
\hline Glutamic-pyruvic transaminase & & $\mathrm{PYR}+\mathrm{GLU} \leftrightarrow \mathrm{AKG}+\mathrm{ALA}$ & Reitzer, 1996 \\
\hline \multicolumn{4}{|l|}{$\begin{array}{l}\text { Biosynthesis of arginine, putrescine, } \\
\text { and spermidine }\end{array}$} \\
\hline$N$-Acetylglutamate synthase & $\arg A$ & $\mathrm{GLU}+\mathrm{ACCOA} \rightarrow \mathrm{COA}+\mathrm{NAGLU}$ & Glansdorf, 1996 \\
\hline $\mathrm{N}$-Acetylglutamate kinase & $\arg B$ & $\mathrm{NAGLU}+\mathrm{ATP} \rightarrow \mathrm{ADP}+\mathrm{NAGLUYP}$ & Glansdorf, 1996 \\
\hline $\begin{array}{l}N \text {-Acetylglutamate phosphate } \\
\text { reductase }\end{array}$ & $\arg C$ & $\begin{array}{l}\text { NAGLUYP + NADPH } \leftrightarrow \text { NADP + PI } \\
\quad+\text { NAGLUSAL }\end{array}$ & Glansdorf, 1996 \\
\hline Acetylornithine aminotransferase & $\arg D$ & NAGLUSAL + GLU $\leftrightarrow$ AKG + NAARON & Glansdorf, 1996 \\
\hline$N$-Acetylornithinase & $\arg E$ & $\mathrm{NAARON} \rightarrow \mathrm{AC}+\mathrm{ORN}$ & Glansdorf, 1996 \\
\hline Carbamoyl phosphate synthetase & $\operatorname{car} A B$ & $\begin{array}{l}\mathrm{GLN}+2 \mathrm{ATP}+\mathrm{CO} 2 \rightarrow \mathrm{GLU}+\mathrm{CAP}+2 \mathrm{ADP} \\
\quad+\mathrm{PI}\end{array}$ & Glansdorf, 1996 \\
\hline Ornithine carbamoyl transferase & $\operatorname{argFI}$ & $\mathrm{ORN}+\mathrm{CAP} \leftrightarrow \mathrm{CITR}+\mathrm{PI}$ & Glansdorf, 1996 \\
\hline Argininosuccinate synthase & $\arg G$ & $\mathrm{CITR}+\mathrm{ASP}+\mathrm{ATP} \leftrightarrow \mathrm{AMP}+\mathrm{PPI}+\mathrm{ARGSUCC}$ & Glansdorf, 1996 \\
\hline Argininosuccinase & $\operatorname{argH}$ & ARGSUCC $\leftrightarrow$ FUM + ARG & Glansdorf, 1996 \\
\hline Ornithine decarboxylase & speC & $\mathrm{ORN} \rightarrow \mathrm{PTRSC}+\mathrm{CO} 2$ & Glansdorf, 1996 \\
\hline Spermidine synthase & $\operatorname{sp} E$ & $\mathrm{PTRSC}+\mathrm{DSAM} \rightarrow \mathrm{SPRMD}+5 \mathrm{MTA}$ & Glansdorf, 1996 \\
\hline Adenosylmethionine decarboxylase & speD & $\mathrm{SAM} \leftrightarrow \mathrm{DSAM}+\mathrm{CO} 2$ & $\begin{array}{l}\text { Glansdorf, 1996; Greene, 1996; } \\
\text { Karp et al., } 1996\end{array}$ \\
\hline Unknown pathway & & $5 \mathrm{MTA} \rightarrow \mathrm{ADN}+\mathrm{MET}$ & Greene, 1996 \\
\hline Agmatine decarboxylase & speA & $\mathrm{ARG} \rightarrow \mathrm{CO} 2+\mathrm{AGM}$ & Glansdorf, 1996 \\
\hline Agmatine ureohydrolase & speB & $\mathrm{AGM} \rightarrow \mathrm{UREA}+\mathrm{PTRSC}$ & Glansdorf, 1996 \\
\hline \multicolumn{4}{|l|}{ Biosynthesis of proline } \\
\hline Glutamyl kinase & proB & $\mathrm{GLU}+\mathrm{ATP} \rightarrow \mathrm{ADP}+\mathrm{GLUP}$ & Leisinger, 1996 \\
\hline $\begin{array}{l}\text { Glutamate-5-semialdehyde } \\
\text { dehydrogenase }\end{array}$ & proA & GLUP + NADPH $\leftrightarrow \mathrm{NADP}+\mathrm{PI}+\mathrm{GLUGSAL}$ & Leisinger, 1996 \\
\hline Pyrroline-5-carboxylate reductase & proC & GLUGSAL + NADPH $\leftrightarrow$ PRO + NADP & Leisinger, 1996 \\
\hline Ornithine oxoacid transaminase & & $\mathrm{ORN}+\mathrm{AKG} \leftrightarrow \mathrm{GLU}+\mathrm{GLUGSAL}$ & Leisinger, 1996 \\
\hline \multicolumn{4}{|l|}{$\begin{array}{l}\text { Biosynthesis of branched-chain amino } \\
\text { acids }\end{array}$} \\
\hline Isopropylmalate synthase & leuA & $\mathrm{ACCOA}+\mathrm{OIVAL} \rightarrow \mathrm{COA}+\mathrm{CBHCAP}$ & Umbarger, 1996 \\
\hline Isopropylmalate isomerase & leuCD & $\mathrm{CBHCAP} \leftrightarrow \mathrm{IPPMAL}$ & Umbarger, 1996 \\
\hline 3-Isopropylmalate dehydrogenase & leuB & $\mathrm{IPPMAL}+\mathrm{NAD} \rightarrow \mathrm{NADH}+\mathrm{OICAP}+\mathrm{CO} 2$ & Umbarger, 1996 \\
\hline Transaminase $\mathrm{C}$ & $i l v E$ & $\mathrm{OICAP}+\mathrm{GLU} \rightarrow \mathrm{AKG}+\mathrm{LEU}$ & Umbarger, 1996 \\
\hline Acetyohydroxy acid synthase & $i l v B$ & $2 \mathrm{PYR} \rightarrow \mathrm{CO} 2+\mathrm{ACLAC}$ & Umbarger, 1996 \\
\hline Acetohydroxy acid isomeroreductase & $i l v C$ & ACLAC + NADPH $\rightarrow$ NADP + DHVAL & Umbarger, 1996 \\
\hline Dihydroxy acid dehydratase & $i l v D$ & DHVAL $\rightarrow$ OIVAL & Umbarger, 1996 \\
\hline Transaminase $\mathrm{C}$ & $i l v E$ & $\mathrm{OIVAL}+\mathrm{GLU} \leftrightarrow \mathrm{AKG}+\mathrm{VAL}$ & Umbarger, 1996 \\
\hline Threonine deaminase & $i l v A$ & $\mathrm{THR} \rightarrow \mathrm{NH} 3+\mathrm{OBUT}$ & Umbarger, 1996 \\
\hline Acetohydroxy acid synthase & $i l v B$ & $\mathrm{OBUT}+\mathrm{PYR} \rightarrow \mathrm{ABUT}+\mathrm{CO} 2$ & Umbarger, 1996 \\
\hline
\end{tabular}


APPENDIX A: CONTINUED

\begin{tabular}{|c|c|c|c|}
\hline Enzyme & Gene & Pathway & Reference \\
\hline Acetohydroxy acid isomeroreductase & $i l v C$ & $\mathrm{ABUT}+\mathrm{NADPH} \rightarrow \mathrm{NADP}+\mathrm{DHMVA}$ & Umbarger, 1996 \\
\hline Dihydroxy acid dehydratase & $i l v D$ & DHMVA $\rightarrow$ OMVAL & Umbarger, 1996 \\
\hline Transaminase B & $i l v E$ & $\mathrm{OMVAL}+\mathrm{GLU} \leftrightarrow \mathrm{AKG}+\mathrm{ILE}$ & Umbarger, 1996 \\
\hline Amino acid oxidase & & $\mathrm{O} 2+\mathrm{ILE} \rightarrow \mathrm{OMVAL}+\mathrm{NH} 3$ & Umbarger, 1996 \\
\hline \multicolumn{4}{|l|}{ Biosynthesis of aromatic amino acids } \\
\hline $\begin{array}{l}\text { 3-Deoxy-D-arabinoheptulosonate-7- } \\
\text { phosphate synthase }\end{array}$ & aroFGH & $\mathrm{E} 4 \mathrm{P}+\mathrm{PEP} \rightarrow \mathrm{PI}+3 \mathrm{DDAH7P}$ & Pittard, 1996 \\
\hline 3-Dehydroquinate synthase & $\operatorname{aroB}$ & 3DDAH7P $\rightarrow$ DQT + PI & Pittard, 1996 \\
\hline 3-Dehydroquinate dehydratase & aroD & DQT $\leftrightarrow$ DHSK & Pittard, 1996 \\
\hline Shikimate dehydrogenase & $\operatorname{aroE}$ & $\mathrm{DHSK}+\mathrm{NADPH} \leftrightarrow \mathrm{SME}+\mathrm{NADP}$ & Pittard, 1996 \\
\hline Shikimate kinase & $\operatorname{aroKL}$ & $\mathrm{SME}+\mathrm{ATP} \rightarrow \mathrm{ADP}+\mathrm{SME} 5 \mathrm{P}$ & Pittard, 1996 \\
\hline $\begin{array}{l}\text { 5-Enolpyruvoylshikimate-3-phosphate } \\
\text { synthase }\end{array}$ & aroA & SME5P + PEP $\leftrightarrow 3 \mathrm{PSME}+\mathrm{PI}$ & Pittard, 1996 \\
\hline Chorismate synthase & aroC & 3PSME $\rightarrow$ PI + CHOR & Pittard, 1996 \\
\hline Chorismate mutase & pheA & $\mathrm{CHOR} \rightarrow$ PHEN & Pittard, 1996 \\
\hline Prephenate dehydratase & pheA & $\mathrm{PHEN} \rightarrow \mathrm{CO} 2+\mathrm{PHPYR}$ & Pittard, 1996 \\
\hline Phenylalanine aminotransferase & tyr $B$ & $\mathrm{PHPYR}+\mathrm{GLU} \leftrightarrow \mathrm{AKG}+\mathrm{PHE}$ & Pittard, 1996 \\
\hline Prephanate dehydrogenase & tyrA & $\mathrm{PHEN}+\mathrm{NADP} \rightarrow \mathrm{HPHPYR}+\mathrm{CO} 2+\mathrm{NADPH}$ & Pittard, 1996 \\
\hline Tyrosine aminotransferase & tyrB & $\mathrm{HPHPYR}+\mathrm{GLU} \leftrightarrow \mathrm{AKG}+\mathrm{TYR}$ & Pittard, 1996 \\
\hline Anthranilate synthase & $\operatorname{trpDE}$ & $\mathrm{CHOR}+\mathrm{GLN} \rightarrow \mathrm{GLU}+\mathrm{PYR}+\mathrm{AN}$ & Pittard, 1996 \\
\hline $\begin{array}{l}\text { Anthranilate phosphoribosyl } \\
\text { transferase }\end{array}$ & $\operatorname{trp} D$ & $\mathrm{AN}+\mathrm{PRPP} \rightarrow \mathrm{PPI}+\mathrm{NPRAN}$ & Pittard, 1996 \\
\hline $\begin{array}{l}\text { Phosphoribosyl anthranilate } \\
\text { isomerase }\end{array}$ & $\operatorname{trpC}$ & NPRAN $\rightarrow$ CPAD5P & Pittard, 1996 \\
\hline Indoleglycerol phosphate synthetase & $\operatorname{trp} C$ & $\mathrm{CPAD} 5 \mathrm{P} \rightarrow \mathrm{CO} 2+\mathrm{IGP}$ & Pittard, 1996 \\
\hline Tryptophan synthetase & $\operatorname{trp} A B$ & $\mathrm{IGP}+\mathrm{SER} \rightarrow \mathrm{T} 3 \mathrm{P} 1+\mathrm{TRP}$ & Pittard, 1996 \\
\hline \multicolumn{4}{|l|}{ Biosynthesis of histidine synthesis } \\
\hline $\begin{array}{l}\text { Phosphoribosyl pyrophosphate } \\
\text { synthetase }\end{array}$ & prs & $\mathrm{R} 5 \mathrm{P}+\mathrm{ATP} \leftrightarrow \mathrm{PRPP}+\mathrm{AMP}$ & Zalkin and Nygaard, 1996 \\
\hline Phosphoribosyl pyrophosphate & hisG & $\mathrm{PRPP}+\mathrm{ATP} \rightarrow \mathrm{PPI}+\mathrm{PRBATP}$ & Winkler, 1996 \\
\hline PR-ATP pyrophosphohydrolase & hisI & PRBATP $\rightarrow$ PPI + PRBAMP & Winkler, 1996 \\
\hline PR-AMP cyclohydrolase & hisI & $\mathrm{PRBAMP} \rightarrow \mathrm{PRFP}$ & Winkler, 1996 \\
\hline 5-ProFAR isomerase & hisA & $\mathrm{PRFP} \rightarrow \mathrm{PRLP}$ & Winkler, 1996 \\
\hline Imidazoleglycerol phosphate synthase & hisFH & $\mathrm{PRLP}+\mathrm{GLN} \rightarrow \mathrm{GLU}+\mathrm{AICAR}+\mathrm{DIMGP}$ & Winkler, 1996 \\
\hline IGP dehydratase & his $B$ & DIMGP $\rightarrow$ IMACP & Winkler, 1996 \\
\hline $\begin{array}{l}\text { L-Histidinol phosphate } \\
\text { aminotransferase }\end{array}$ & hisC & $\mathrm{IMACP}+\mathrm{GLU} \rightarrow \mathrm{AKG}+\mathrm{HISOLP}$ & Winkler, 1996 \\
\hline Hol- $P$-phosphatase & hisB & $\mathrm{HISOLP} \rightarrow \mathrm{PI}+\mathrm{HISOL}$ & Winkler, 1996 \\
\hline Hol dehydrogenase & hisD & $\mathrm{HISOL}+2 \mathrm{NAD} \rightarrow 2 \mathrm{NADH}+\mathrm{HIS}$ & Winkler, 1996 \\
\hline \multicolumn{4}{|l|}{$\begin{array}{l}\text { Biosynthesis of serine, glycine, and } \\
\text { 1-carbon units }\end{array}$} \\
\hline 3-Phosphoglycerate dehydrogenase & $\operatorname{ser} A$ & $3 \mathrm{PDGL}+\mathrm{NAD} \rightarrow \mathrm{NADH}+\mathrm{PHP}$ & Stauffer, 1996 \\
\hline Phosphoserine transaminase & $\operatorname{ser} C$ & $\mathrm{PHP}+\mathrm{GLU} \rightarrow \mathrm{AKG}+3 \mathrm{PSER}$ & Stauffer, 1996 \\
\hline Phosphoserine phosphatase & $\operatorname{ser} B$ & 3PSER $\rightarrow$ PI + SER & Stauffer, 1996 \\
\hline Serine hydroxymethyltransferase & glyA & $\mathrm{GLY}+\mathrm{METTHF} \leftrightarrow \mathrm{THF}+\mathrm{SER}$ & Matthews, 1996; Stauffer, 1996 \\
\hline Glycine cleavage system & gcvHTP & $\begin{array}{l}\mathrm{GLY}+\mathrm{THF}+\mathrm{NAD} \rightarrow \mathrm{METTHF}+\mathrm{NADH} \\
\quad+\mathrm{CO} 2+\mathrm{NH} 3\end{array}$ & Matthews, 1996; Stauffer, 1996 \\
\hline Threonine dehydrogenase & thd & $\mathrm{THR}+\mathrm{NAD} \leftrightarrow \mathrm{AABK}+\mathrm{NADH}$ & Matthews, 1996 \\
\hline Amino- $b$-ketobutyrase & $k b l$ & $\mathrm{AABK}+\mathrm{COA} \leftrightarrow \mathrm{GLY}+\mathrm{ACCOA}$ & Matthews, 1996 \\
\hline Formate dehydrogenase & & FORMATE + NAD $\rightarrow$ NADH + $\mathrm{CO} 2$ & Kadner, 1996 \\
\hline Formate THF ligase & & $\mathrm{THF}+\mathrm{FORMATE}+\mathrm{ATP} \rightarrow \mathrm{ADP}+\mathrm{PI}+\mathrm{FTHF}$ & Michal, 1993 \\
\hline Formyl THF deformylase & & FTHF $\rightarrow$ FORMATE + THF & Michal, 1993 \\
\hline Dihydrofolate reductase (STEP 2) & & $\mathrm{DHF}+\mathrm{NADPH} \leftrightarrow \mathrm{NADP}+\mathrm{THF}$ & Michal, 1993 \\
\hline \multicolumn{4}{|l|}{ Biosynthesis of cysteine } \\
\hline ATP sulfhydrolase & cys $D N$ & $\mathrm{H} 2 \mathrm{SO} 4+\mathrm{ATP} \rightarrow \mathrm{PPI}+\mathrm{APS}$ & Kredich, 1996 \\
\hline ATS kinase & cysC & $\mathrm{APS}+\mathrm{ATP} \rightarrow \mathrm{ADP}+\mathrm{PAPS}$ & Kredich, 1996 \\
\hline PAPS sulfotransferase & cys $H$ & $\mathrm{PAPS}+\mathrm{NADPH} \rightarrow \mathrm{NADP}+\mathrm{H} 2 \mathrm{SO} 3+\mathrm{PAP}$ & Kredich, 1996 \\
\hline NAHPH-sulfite reductase & cysGIJ & $\mathrm{H} 2 \mathrm{SO} 3+3 \mathrm{NADPH} \leftrightarrow 3 \mathrm{NADP}+\mathrm{H} 2 \mathrm{~S}$ & Kredich, 1996 \\
\hline Serine transacetylase & cysE & $\mathrm{SER}+\mathrm{ACCOA} \leftrightarrow \mathrm{COA}+\mathrm{ASER}$ & Kredich, 1996 \\
\hline$O$-Acetylserine (thiol)-lyase & cys $K M$ & $\mathrm{ASER}+\mathrm{H} 2 \mathrm{~S} \rightarrow \mathrm{AC}+\mathrm{CYS}$ & Kredich, 1996 \\
\hline Sulfotransferase & & $\mathrm{PAP}+\mathrm{H} 2 \mathrm{SO} 3 \leftrightarrow \mathrm{PAPS}$ & \\
\hline Adenylyl sulfate kinase & & $\mathrm{PAPS}+\mathrm{ADP} \rightarrow \mathrm{ATP}+\mathrm{APS}$ & \\
\hline
\end{tabular}


APPENDIX A: CONTINUED

\begin{tabular}{|c|c|c|c|}
\hline Enzyme & Gene & Pathway & Reference \\
\hline \multicolumn{4}{|l|}{ Biosynthesis of threonine and lysine } \\
\hline Aspartate kinase & thrA & $\mathrm{ASP}+\mathrm{ATP} \leftrightarrow \mathrm{ADP}+\mathrm{BASP}$ & Patte, 1996 \\
\hline $\begin{array}{l}\text { Aspartate semialdehyde } \\
\text { dehydrogenase }\end{array}$ & asd & $\mathrm{BASP}+\mathrm{NADPH} \leftrightarrow \mathrm{NADP}+\mathrm{PI}+\mathrm{ASPSA}$ & Patte, 1996 \\
\hline Homoserine dehydrogenase & thrA & ASPSA + NADPH $\leftrightarrow \mathrm{NADP}+\mathrm{HSER}$ & Patte, 1996 \\
\hline Homoserine kinase & thrB & $\mathrm{HSER}+\mathrm{ATP} \rightarrow \mathrm{ADP}+\mathrm{PHSER}$ & Patte, 1996 \\
\hline Threonine synthase & thrC & $\mathrm{PHSER} \rightarrow \mathrm{PI}+\mathrm{THR}$ & Patte, 1996 \\
\hline Dihydrodipicolinate synthase & $\operatorname{dap} A$ & $\mathrm{ASPSA}+\mathrm{PYR} \rightarrow \mathrm{D} 23 \mathrm{PIC}$ & Patte, 1996 \\
\hline Dihydrodipicolinate reductase & $d a p B$ & $\mathrm{D} 23 \mathrm{PIC}+\mathrm{NADPH} \rightarrow \mathrm{NADP}+\mathrm{PIP} 26 \mathrm{DX}$ & Patte, 1996 \\
\hline Tetrahydrodipicolinate succinylase & $\operatorname{dapD}$ & $\mathrm{PIP} 26 \mathrm{DX}+\mathrm{SUCCOA} \rightarrow \mathrm{COA}+\mathrm{NS} 2 \mathrm{~A} 6 \mathrm{O}$ & Patte, 1996 \\
\hline $\begin{array}{l}\text { Succinyl diaminopimelate } \\
\text { aminotransferase }\end{array}$ & $\operatorname{dap} C$ & $\mathrm{NS} 2 \mathrm{~A} 6 \mathrm{O}+\mathrm{GLU} \leftrightarrow \mathrm{AKG}+\mathrm{NS} 26 \mathrm{DP}$ & Patte, 1996 \\
\hline $\begin{array}{l}\text { Succinyl diaminopimelate } \\
\text { desuccinylase }\end{array}$ & dapE & $\mathrm{NS} 26 \mathrm{DP} \rightarrow \mathrm{SUCC}+\mathrm{D} 26 \mathrm{PIM}$ & Patte, 1996 \\
\hline Diaminopimelate epimerase & dapF & D26PIM $\leftrightarrow$ MDAP & Patte, 1996 \\
\hline Diaminopimelate decarboxylase & lys $A$ & $\mathrm{MDAP} \rightarrow \mathrm{CO} 2+\mathrm{LYS}$ & Patte, 1996 \\
\hline \multicolumn{4}{|l|}{ Biosynthesis of methionine } \\
\hline Homoserine transsuccinylase & metA & $\mathrm{HSER}+\mathrm{SUCCOA} \rightarrow \mathrm{COA}+$ OSLHSER & Greene, 1996 \\
\hline Cystathionine synthase & $m e t B$ & $\mathrm{OSLHSER}+\mathrm{CYS} \rightarrow \mathrm{SUCC}+\mathrm{HCYS}+\mathrm{PYR}+\mathrm{NH} 3$ & Greene, 1996 \\
\hline Cystathionase & metC & $\mathrm{HCYS}+\mathrm{ADN} \leftrightarrow \mathrm{SAH}$ & Greene, 1996 \\
\hline Methionine synthase & metEH & $\mathrm{HCYS}+\mathrm{MTHF} \rightarrow \mathrm{MET}+\mathrm{THF}$ & Greene, 1996; Matthews, 1996 \\
\hline Methionyl adenosyl transferase & metK & $\mathrm{MET}+\mathrm{ATP} \rightarrow \mathrm{PPI}+\mathrm{PI}+\mathrm{SAM}$ & Greene, 1996; Matthews, 1996 \\
\hline \multicolumn{4}{|l|}{ Biosynthesis of purine nucleotides } \\
\hline Glutamine PRPP amidotransferase & purF & $\mathrm{PRPP}+\mathrm{GLN} \rightarrow \mathrm{PPI}+\mathrm{GLU}+\mathrm{PRAM}$ & Zalkin and Nygaard, 1996 \\
\hline GAR synthetase & purD & $\mathrm{PRAM}+\mathrm{ATP}+\mathrm{GLY} \leftrightarrow \mathrm{ADP}+\mathrm{PI}+\mathrm{GAR}$ & Zalkin and Nygaard, 1996 \\
\hline GAR transformylase & purNT & $\mathrm{GAR}+\mathrm{FTHF} \rightarrow \mathrm{THF}+\mathrm{FGAR}$ & Zalkin and Nygaard, 1996 \\
\hline FGAM synthetase & purL & $\mathrm{FGAR}+\mathrm{ATP}+\mathrm{GLN} \rightarrow \mathrm{GLU}+\mathrm{ADP}+\mathrm{PI}+\mathrm{FGAM}$ & Zalkin and Nygaard, 1996 \\
\hline AIR synthetase & purM & $\mathrm{FGAM}+\mathrm{ATP} \rightarrow \mathrm{ADP}+\mathrm{PI}+\mathrm{AIR}$ & Zalkin and Nygaard, 1996 \\
\hline RCAIM synthetase & purK & $\mathrm{AIR}+\mathrm{CO} 2 \leftrightarrow \mathrm{RCAIM}$ & Zalkin and Nygaard, 1996 \\
\hline PRSCAIM synthetase & purE & $\mathrm{RCAIM}+\mathrm{ATP}+\mathrm{ASP} \leftrightarrow \mathrm{ADP}+\mathrm{PI}+\mathrm{PRSCAIM}$ & Zalkin and Nygaard, 1996 \\
\hline Adenylosuccinate lyase & purB & PRSCAIM $\leftrightarrow$ FUM + AICAR & Zalkin and Nygaard, 1996 \\
\hline AICAR transformylase & purH & $\mathrm{AICAR}+\mathrm{FTHF} \leftrightarrow \mathrm{THF}+\mathrm{PRFICA}$ & Zalkin and Nygaard, 1996 \\
\hline IMP cyclohydrolase & purH & PRFICA $\leftrightarrow$ IMP & Zalkin and Nygaard, 1996 \\
\hline Adenylosuccinate synthetase & purA & $\mathrm{IMP}+\mathrm{GTP}+\mathrm{ASP} \rightarrow \mathrm{GDP}+\mathrm{PI}+\mathrm{ASUC}$ & Zalkin and Nygaard, 1996 \\
\hline Adenylosuccinate lyase & purB & $\mathrm{ASUC} \leftrightarrow \mathrm{FUM}+\mathrm{AMP}$ & Zalkin and Nygaard, 1996 \\
\hline AMP phosphatase & & $\mathrm{AMP} \rightarrow \mathrm{PI}+\mathrm{ADN}$ & Zalkin and Nygaard, 1996 \\
\hline Adenylate kinase & $a d k$ & $\mathrm{ATP}+\mathrm{ADN} \rightarrow \mathrm{ADP}+\mathrm{AMP}$ & Zalkin and Nygaard, 1996 \\
\hline Adenylate kinase & $a d k$ & $\mathrm{ATP}+\mathrm{AMP} \rightarrow 2 \mathrm{ADP}$ & Zalkin and Nygaard, 1996 \\
\hline IMP dehydrogenase & guaB & $\mathrm{IMP}+\mathrm{NAD} \rightarrow \mathrm{NADH}+\mathrm{XMP}$ & Zalkin and Nygaard, 1996 \\
\hline GMP synthetase & guaA & $\mathrm{XMP}+\mathrm{ATP}+\mathrm{GLN} \rightarrow \mathrm{GLU}+\mathrm{AMP}+\mathrm{PPI}+\mathrm{GMP}$ & Zalkin and Nygaard, 1996 \\
\hline GMP kinase & $g m k$ & $\mathrm{GMP}+\mathrm{ATP} \leftrightarrow \mathrm{GDP}+\mathrm{ADP}$ & Zalkin and Nygaard, 1996 \\
\hline GDP kinase & $g m k$ & $\mathrm{GDP}+\mathrm{ATP} \leftrightarrow \mathrm{GTP}+\mathrm{ADP}$ & Zalkin and Nygaard, 1996 \\
\hline Ribonucleotide reductase (ADP) & deoD & $\mathrm{ADP}+\mathrm{NADPH} \rightarrow \mathrm{DADP}+\mathrm{NADP}$ & Zalkin and Nygaard, 1996 \\
\hline Ribonucleotide reductase (GDP) & deoD & $\mathrm{GDP}+\mathrm{NADPH} \rightarrow \mathrm{DGDP}+\mathrm{NADP}$ & Zalkin and Nygaard, 1996 \\
\hline Ribonucleotide reductase (ATP) & deoD & $\mathrm{ATP}+\mathrm{NADPH} \rightarrow \mathrm{NADP}+\mathrm{DATP}$ & Zalkin and Nygaard, 1996 \\
\hline Ribonucleotide reductase (GTP) & deoD & $\mathrm{GTP}+\mathrm{NADPH} \rightarrow \mathrm{NADP}+\mathrm{DGTP}$ & Zalkin and Nygaard, 1996 \\
\hline dADP kinase & $n c k$ & $\mathrm{DADP}+\mathrm{ATP} \leftrightarrow \mathrm{DATP}+\mathrm{ADP}$ & Zalkin and Nygaard, 1996 \\
\hline dGDP kinase & $n d k$ & $\mathrm{DGDP}+\mathrm{ATP} \leftrightarrow \mathrm{DGTP}+\mathrm{ADP}$ & Zalkin and Nygaard, 1996 \\
\hline dAMP kinase & $n d k$ & $\mathrm{DAMP}+\mathrm{ATP} \leftrightarrow \mathrm{ADP}+\mathrm{DADP}$ & Zalkin and Nygaard, 1996 \\
\hline dGMP kinase & $n d k$ & $\mathrm{DGMP}+\mathrm{ATP} \leftrightarrow \mathrm{DGDP}+\mathrm{ADP}$ & Zalkin and Nygaard, 1996 \\
\hline \multicolumn{4}{|l|}{ Biosynthesis of pyrimidines } \\
\hline Aspartate carbamoyl transferase & pyrBI & $\mathrm{CAP}+\mathrm{ASP} \rightarrow \mathrm{CAASP}+\mathrm{PI}$ & Neuhard and Klein, 1996 \\
\hline Dihydroorotase & pyrC & $\mathrm{CAASP} \leftrightarrow \mathrm{DOROA}$ & Neuhard and Klein, 1996 \\
\hline Dihydroorotate dehydrogenase & pyrD & $\mathrm{DOROA}+\mathrm{NAD} \leftrightarrow \mathrm{NADH}+\mathrm{OROA}$ & Neuhard and Klein, 1996 \\
\hline Orotate phosphoribosyl transferase & pyrE & $\mathrm{OROA}+\mathrm{PRPP} \leftrightarrow \mathrm{PPI}+\mathrm{OMP}$ & Neuhard and Klein, 1996 \\
\hline OMP decarboxylase & pyrF & $\mathrm{OMP} \rightarrow \mathrm{CO} 2+\mathrm{UMP}$ & Neuhard and Klein, 1996 \\
\hline UMP kinase & pyrH & $\mathrm{UMP}+\mathrm{ATP} \leftrightarrow \mathrm{UDP}+\mathrm{ADP}$ & Neuhard and Klein, 1996 \\
\hline UDP kinase & $n d k$ & $\mathrm{UDP}+\mathrm{ATP} \leftrightarrow \mathrm{UTP}+\mathrm{ADP}$ & Neuhard and Klein, 1996 \\
\hline CTP synthetase & pyrG & $\mathrm{UTP}+\mathrm{GLN}+\mathrm{ATP} \rightarrow \mathrm{GLU}+\mathrm{CTP}+\mathrm{ADP}+\mathrm{PI}$ & Neuhard and Klein, 1996 \\
\hline CMP kinase & $n d k$ & $\mathrm{CMP}+\mathrm{ATP} \leftrightarrow \mathrm{CDP}+\mathrm{ADP}$ & Neuhard and Klein, 1996 \\
\hline CDP kinase & $n d k$ & $\mathrm{CDP}+\mathrm{ATP} \leftrightarrow \mathrm{CTP}+\mathrm{ADP}$ & Neuhard and Klein, 1996 \\
\hline Deoxycytidilate deaminase & $c d d$ & $\mathrm{DCMP} \rightarrow \mathrm{NH} 3+\mathrm{DUMP}$ & Neuhard and Klein, 1996 \\
\hline
\end{tabular}


APPENDIX A: CONTINUED

\begin{tabular}{|c|c|c|c|}
\hline Enzyme & Gene & Pathway & Reference \\
\hline Ribonucleotide reductase (CDP) & $n r d A B$ & $\mathrm{CDP}+\mathrm{NADPH} \rightarrow \mathrm{DCDP}+\mathrm{NADP}$ & Neuhard and Klein, 1996 \\
\hline Ribonucleotide reductase (UDP) & $n r d A B$ & $\mathrm{UDP}+\mathrm{NADPH} \rightarrow \mathrm{DUDP}+\mathrm{NADP}$ & Neuhard and Klein, 1996 \\
\hline Ribonucleotide reductase (CTP) & $n r d A B$ & $\mathrm{CTP}+\mathrm{NADPH} \rightarrow \mathrm{DCTP}+\mathrm{NADP}$ & Neuhard and Klein, 1996 \\
\hline Ribonucleotide reductase (UTP) & $n r d A B$ & $\mathrm{UTP}+\mathrm{NADPH} \rightarrow \mathrm{NADP}+\mathrm{DUTP}$ & Neuhard and Klein, 1996 \\
\hline dCMP kinase & $n d k$ & $\mathrm{DCMP}+\mathrm{ATP} \leftrightarrow \mathrm{ADP}+\mathrm{DCDP}$ & Neuhard and Klein, 1996 \\
\hline dCDP kinase & $n d k$ & $\mathrm{DCDP}+\mathrm{ATP} \leftrightarrow \mathrm{DCTP}+\mathrm{ADP}$ & Neuhard and Klein, 1996 \\
\hline dUDP kinase & $n d k$ & $\mathrm{DUDP}+\mathrm{ATP} \leftrightarrow \mathrm{DUTP}+\mathrm{ADP}$ & Neuhard and Klein, 1996 \\
\hline dUTP pyrophosphatase & $d u t$ & DUTP $\rightarrow$ PPI + DUMP & Neuhard and Klein, 1996 \\
\hline dUMP kinase & $n d k$ & $\mathrm{DUMP}+\mathrm{ATP} \leftrightarrow \mathrm{ADP}+\mathrm{DUDP}$ & Neuhard and Klein, 1996 \\
\hline Thymidilate synthetase & thyA & $\mathrm{DUMP}+\mathrm{METTHF} \rightarrow \mathrm{DHF}+\mathrm{TMP}$ & $\begin{array}{l}\text { Matthews, 1996; Neuhard and } \\
\quad \text { Klein, } 1996\end{array}$ \\
\hline TMP kinase & $t m k$ & $\mathrm{TMP}+\mathrm{ATP} \leftrightarrow \mathrm{ADP}+\mathrm{TDP}$ & Neuhard and Klein, 1996 \\
\hline TDP kinase & $n d k$ & $\mathrm{TDP}+\mathrm{ATP} \leftrightarrow \mathrm{ADP}+\mathrm{TTP}$ & Neuhard and Klein, 1996 \\
\hline \multicolumn{4}{|l|}{ Biosynthesis of THF } \\
\hline Methylene THF reductase & $m e t F$ & $\mathrm{METTHF}+\mathrm{NADH} \rightarrow \mathrm{NAD}+\mathrm{MTHF}$ & Matthews, 1996 \\
\hline Methylene THF dehydrogenase & fold & METTHF + NADP $\leftrightarrow$ METHF + NADPH & Matthews, 1996 \\
\hline $\begin{array}{l}\text { Methenyl tetrahydrofolate } \\
\text { cyclehydrolase }\end{array}$ & folD & $\mathrm{METHF} \leftrightarrow \mathrm{FTHF}$ & Matthews, 1996 \\
\hline \multicolumn{4}{|l|}{ Biosynthesis of membrane lipids } \\
\hline Acetyl-CoA carboxylase & $a c c$ & $\mathrm{ACCOA}+\mathrm{ATP}+\mathrm{CO} 2 \leftrightarrow \mathrm{MALCOA}+\mathrm{ADP}+\mathrm{PI}$ & Cronan and Rock, 1996 \\
\hline Malonyl-CoA:ACP transacylase & $m t a$ & $\mathrm{MALCOA}+\mathrm{ACP} \leftrightarrow \mathrm{MALACP}+\mathrm{COA}$ & Cronan and Rock, 1996 \\
\hline$b$-Ketoacyl-ACP synthase I & kas1 & $\mathrm{MALACP} \rightarrow \mathrm{ACACP}+\mathrm{CO} 2$ & Cronan and Rock, 1996 \\
\hline Acetyl-CoA:ACP transacylase & ata & $\mathrm{ACACP}+\mathrm{COA} \leftrightarrow \mathrm{ACCOA}+\mathrm{ACP}$ & Cronan and Rock, 1996 \\
\hline$b$-Ketoacyl-ACP synthase I (C14:0) & $f a b$ & $\begin{array}{l}\mathrm{ACACP}+6 \mathrm{MALACP}+12 \mathrm{NADPH} \rightarrow \mathrm{C} 14: 0 \mathrm{ACP} \\
+6 \mathrm{CO} 2+12 \mathrm{NADP}+6 \mathrm{ACP}\end{array}$ & Cronan and Rock, 1996 \\
\hline$b$-Ketoacyl-ACP synthase I (C14:1) & $f a b$ & $\begin{array}{l}\mathrm{ACACP}+6 \mathrm{MALACP}+11 \mathrm{NADPH} \rightarrow \mathrm{C} 14: 1 \mathrm{ACP} \\
+6 \mathrm{CO} 2+11 \mathrm{NADP}+6 \mathrm{ACP}\end{array}$ & Cronan and Rock, 1996 \\
\hline$b$-Ketoacyl-ACP synthase I (C16:0) & $f a b$ & $\begin{array}{l}\mathrm{ACACP}+7 \mathrm{MALACP}+14 \mathrm{NADPH} \rightarrow \mathrm{C} 16: 0 \mathrm{ACP} \\
+7 \mathrm{CO} 2+14 \mathrm{NADP}+7 \mathrm{ACP}\end{array}$ & Cronan and Rock, 1996 \\
\hline$b$-Ketoacyl-ACP synthase I (C16:1) & $f a b$ & $\begin{array}{l}\mathrm{ACACP}+7 \mathrm{MALACP}+13 \mathrm{NADPH} \rightarrow \mathrm{C} 16: 1 \mathrm{ACP} \\
+7 \mathrm{CO} 2+13 \mathrm{NADP}+7 \mathrm{ACP}\end{array}$ & Cronan and Rock, 1996 \\
\hline$b$-Ketoacyl-ACP synthase I (C18:1) & $f a b$ & $\begin{array}{l}\mathrm{ACACP}+8 \mathrm{MALACP}+15 \mathrm{NADPH} \rightarrow \mathrm{C} 18: 1 \mathrm{ACP} \\
+8 \mathrm{CO} 2+15 \mathrm{NADP}+8 \mathrm{ACP}\end{array}$ & Cronan and Rock, 1996 \\
\hline Glycerol-3-phosphate dehydrogenase & gpsA & $\mathrm{NADH}+\mathrm{T} 3 \mathrm{P} 2 \leftrightarrow \mathrm{GL} 3 \mathrm{P}+\mathrm{NAD}$ & Cronan and Rock, 1996 \\
\hline 1-Acyl-G3P acyltransferase & pls & $\begin{array}{l}\mathrm{GL} 3 \mathrm{P}+0.03 \mathrm{C} 14: 0 \mathrm{ACP}+0.086 \mathrm{C} 14: 1 \mathrm{ACP}+0.607 \\
\mathrm{C} 16: 0 \mathrm{ACP}+0.12 \mathrm{C} 16: 1 \mathrm{ACP}+0.85 \mathrm{C} 18: 1 \mathrm{ACP} \\
\quad \rightarrow \mathrm{PA}+1.693 \mathrm{ACP}\end{array}$ & Cronan and Rock, 1996 \\
\hline CDP-Diacylglycerol synthetase & $c d s A$ & $\mathrm{PA}+\mathrm{CTP} \leftrightarrow \mathrm{CDPDG}+\mathrm{PPI}$ & Cronan and Rock, 1996 \\
\hline Phosphatidylserine synthase & pssA & $\mathrm{CDPDG}+\mathrm{SER} \leftrightarrow \mathrm{CMP}+\mathrm{PS}$ & Cronan and Rock, 1996 \\
\hline PS decarboxylase & psd & $\mathrm{PS} \rightarrow \mathrm{PE}+\mathrm{CO} 2$ & Cronan and Rock, 1996 \\
\hline $\begin{array}{l}\text { Phosphatidylglycerol phosphate } \\
\text { synthase }\end{array}$ & $\operatorname{pgs} A$ & $\mathrm{CDPDG}+\mathrm{GL3P} \leftrightarrow \mathrm{CMP}+\mathrm{PGP}$ & Cronan and Rock, 1996 \\
\hline $\begin{array}{l}\text { Phosphatidylglycerol phosphate } \\
\text { phosphate }\end{array}$ & pgpA & $\mathrm{PGP} \rightarrow \mathrm{PI}+\mathrm{PG}$ & Cronan and Rock, 1996 \\
\hline Cardiolipin synthase & $c l s$ & $\mathrm{PG}+\mathrm{CDPDG} \leftrightarrow \mathrm{CL}+\mathrm{CMP}$ & Cronan and Rock, 1996 \\
\hline \multicolumn{4}{|l|}{ Biosynthesis of isoprenoids } \\
\hline Aldose reductase & & $\mathrm{GL}+\mathrm{NADP} \leftrightarrow \mathrm{NADPH}+\mathrm{GLAL}$ & White, 1996 \\
\hline Glyceraldehyde kinase & & $\mathrm{GLAL}+\mathrm{ATP} \rightarrow \mathrm{ADP}+\mathrm{T} 3 \mathrm{P} 1$ & White, 1996 \\
\hline $\begin{array}{l}\text { Hydroxymethyl-glutaryl-CoA } \\
\text { synthase }\end{array}$ & & $3 \mathrm{ACCOA} \rightarrow 2 \mathrm{COA}+\mathrm{HMGCOA}$ & White, 1996 \\
\hline 3-Methyl-glutaconyl-CoA hydratase & & HMGCOA $\leftrightarrow$ TMGCOA & White, 1996 \\
\hline IPP synthase & & $\begin{array}{l}\mathrm{HMGCOA}+2 \mathrm{NADPH}+3 \mathrm{ATP} \rightarrow \mathrm{COA} \\
+2 \mathrm{NADP}+3 \mathrm{ADP}+1 \mathrm{PI}+\mathrm{CO} 2+\mathrm{IPPP}\end{array}$ & White, 1996 \\
\hline GGPP synthase & & $4 \mathrm{IPPP} \rightarrow 3 \mathrm{PPI}+\mathrm{GGPP}$ & White, 1996 \\
\hline Methylcrotonyl-CoA carboxylase & & $\mathrm{MCCOA}+\mathrm{ATP}+\mathrm{CO} 2 \leftrightarrow \mathrm{ADP}+\mathrm{TMGCOA}+\mathrm{PI}$ & Michal, 1996 \\
\hline Acyl-CoA dehydrogenase & & $\mathrm{ISOVCOA}+\mathrm{Q} \leftrightarrow \mathrm{QH} 2+\mathrm{MCCOA}$ & Michal, 1996 \\
\hline 2-Keto-isocaproate decarboxylase & & $\begin{array}{l}\mathrm{OICAP}+\mathrm{COA}+\mathrm{NADP} \rightarrow \mathrm{NADPH}+\mathrm{CO} 2+ \\
\text { ISOVCOA }\end{array}$ & Michal, 1996 \\
\hline \multicolumn{4}{|l|}{ Biosynthesis of quinone } \\
\hline Chorismate pyruvate-lyase & $u b i C$ & $\mathrm{CHOR} \rightarrow 4 \mathrm{HBZ}+\mathrm{PYR}$ & Meganathan, 1996 \\
\hline $\begin{array}{l}\text { Hydroxybenzoate octaprenyl- } \\
\text { transferase }\end{array}$ & ubiADX & $4 \mathrm{HBZ}+\mathrm{GGPP} \rightarrow 2 \mathrm{PPP}+\mathrm{CO} 2+\mathrm{PPI}$ & Meganathan, 1996 \\
\hline
\end{tabular}


APPENDIX A: CONTINUED

\begin{tabular}{|c|c|c|c|}
\hline Enzyme & Gene & Pathway & Reference \\
\hline $2 \mathrm{O} 6 \mathrm{H}$ synthetase & $u b i B$ & $2 \mathrm{PPP}+\mathrm{O} 2 \rightarrow 2 \mathrm{O} 6 \mathrm{H}$ & Meganathan, 1996 \\
\hline $\mathrm{QH} 2$ synthetase & ubiEFGH & $2 \mathrm{O} 6 \mathrm{H}+2 \mathrm{O} 2+3 \mathrm{SAM} \rightarrow 3 \mathrm{SAH}+\mathrm{QH} 2$ & Meganathan, 1996 \\
\hline \multicolumn{4}{|l|}{ Biosynthesis of riboflavin } \\
\hline GTP cyclohydrolase & $\operatorname{ribA}$ & $\mathrm{GTP} \rightarrow \mathrm{D} 6 \mathrm{RP} 5 \mathrm{P}+\mathrm{CO} 2+\mathrm{PPI}$ & Bacher et al., 1996 \\
\hline Pyimidine deaminase & $r i b D$ & $\mathrm{D} 6 \mathrm{RP} 5 \mathrm{P} \rightarrow \mathrm{A} 6 \mathrm{RP} 5 \mathrm{P}+\mathrm{NH} 3$ & Bacher et al., 1996 \\
\hline Pyrimidine reductase & $r i b D$ & A6RP5P + NADPH $\rightarrow$ A6RP5P2 + NADP & Bacher et al., 1996 \\
\hline Phosphatase & & $\mathrm{A} 6 \mathrm{RP} 5 \mathrm{P} 2 \rightarrow \mathrm{A} 6 \mathrm{RP}+\mathrm{PI}$ & Bacher et al., 1996 \\
\hline $\begin{array}{l}\text { 3,4-Dihydroxy-2-butanone-4-phosphate } \\
\text { synthase }\end{array}$ & $r i b B$ & $\mathrm{~A} 6 \mathrm{RP} \rightarrow \mathrm{DB} 4 \mathrm{P}+\mathrm{FORMATE}$ & Bacher et al., 1996 \\
\hline $\begin{array}{l}\text { 6,7-Dimethyl-8-ribityllumazine } \\
\text { synthase }\end{array}$ & $r i b E$ & $\mathrm{DB} 4 \mathrm{P}+\mathrm{A} 6 \mathrm{RP} \rightarrow \mathrm{D} 8 \mathrm{RL}+\mathrm{PI}$ & Bacher et al., 1996 \\
\hline Riboflavin synthase & $r i b C$ & $2 \mathrm{D} 8 \mathrm{RL} \rightarrow \mathrm{RIBOFLAVIN}+\mathrm{A} 6 \mathrm{RP}$ & Bacher et al., 1996 \\
\hline Riboflavin kinase & $r i b F$ & RIBOFLAVIN + ATP $\rightarrow$ FMN + ADP & Bacher et al., 1996 \\
\hline FAD synthetase & $r i b F$ & $\mathrm{FMN}+\mathrm{ATP} \rightarrow \mathrm{FAD}+\mathrm{PPI}$ & Bacher et al., 1996 \\
\hline \multicolumn{4}{|l|}{ Biosynthesis of folate } \\
\hline GTP cyclohydrolase & folE & GTP $\rightarrow$ FORMATE + AHTD & Green et al., 1996 \\
\hline $\begin{array}{l}\text { H2Neopterin triphosphate } \\
\text { pyrophosphatase }\end{array}$ & & AHTD $\rightarrow 3$ PI + DHP & Green et al., 1996 \\
\hline H2Neopterin aldolase & & $\mathrm{DHP} \rightarrow \mathrm{AHHMP}+\mathrm{GLAL}$ & Green et al., 1996 \\
\hline $\begin{array}{l}\text { 6-Hydroxymethyl H2pterin } \\
\text { pyrophosphokinase }\end{array}$ & folK & $\mathrm{AHHMP}+\mathrm{ATP} \rightarrow \mathrm{AMP}+\mathrm{AHHMD}$ & Green et al., 1996 \\
\hline $\mathrm{H} 2$ pteroate synthase & folP & $\mathrm{AN}+\mathrm{AHHMD} \rightarrow \mathrm{PPI}+\mathrm{DHD}$ & Green et al., 1996 \\
\hline Dihydrofolate reductase & folA & $\mathrm{DHD}+\mathrm{ATP}+\mathrm{GLU} \rightarrow \mathrm{ADP}+\mathrm{PI}+\mathrm{DHF}$ & Green et al., 1996 \\
\hline \multicolumn{4}{|l|}{ Biosynthesis of coenzyme A } \\
\hline CoA Synthase & $\operatorname{panBCDE}$ & $\begin{array}{l}\mathrm{OIVAL}+\mathrm{METTHF}+\mathrm{NADPH}+\mathrm{ALA}+\mathrm{CTP} \\
\quad+4 \mathrm{ATP}+\mathrm{CYS} \rightarrow \mathrm{THF}+\mathrm{NADP}+\mathrm{AMP}+2 \mathrm{PPI} \\
+2 \mathrm{ADP}+\mathrm{CO} 2+\mathrm{COA}\end{array}$ & $\begin{array}{l}\text { Jackowski, } 1996 \\
\text { (Lumped pathway) }\end{array}$ \\
\hline ACP Synthase & acpS & $\mathrm{COA} \rightarrow 35 \mathrm{ADP}+\mathrm{ACP}$ & Jackowski, 1996 \\
\hline 3,5-ADP phosphatase & & $35 \mathrm{ADP} \rightarrow \mathrm{AMP}+\mathrm{PI}$ & \\
\hline \multicolumn{4}{|l|}{ Biosynthesis of NAD } \\
\hline Quinolate synthase & $\operatorname{nad} A B$ & $\mathrm{ASP}+\mathrm{FAD}+\mathrm{T} 3 \mathrm{P} 2 \rightarrow \mathrm{FADH} 2+\mathrm{PI}+\mathrm{QNL}$ & Penfound and Foster, 1996 \\
\hline Quinolate phosphoribosyl transferase & $\operatorname{nadC}$ & $\mathrm{QNL}+\mathrm{PRPP} \rightarrow \mathrm{PPI}+\mathrm{NICNT}+\mathrm{CO} 2$ & Penfound and Foster, 1996 \\
\hline NAMN adenylyl tranferase & $\operatorname{nadD}$ & $\mathrm{NICNT}+\mathrm{ATP} \rightarrow \mathrm{PPI}+\mathrm{DANAD}$ & Penfound and Foster, 1996 \\
\hline Deamido-NAD ammonia ligase & $\operatorname{nadE}$ & $\mathrm{DANAD}+\mathrm{ATP}+\mathrm{NH} 3 \rightarrow \mathrm{AMP}+\mathrm{PPI}+\mathrm{NAD}$ & Penfound and Foster, 1996 \\
\hline NAD kinase & & $\mathrm{NAD}+\mathrm{ATP} \rightarrow \mathrm{NADP}+\mathrm{ADP}$ & Penfound and Foster, 1996 \\
\hline NADP phosphatase & & $\mathrm{NADP} \rightarrow \mathrm{NAD}+\mathrm{PI}$ & Penfound and Foster, 1996 \\
\hline \multicolumn{4}{|l|}{ Biosynthesis of porphyrins and hemes } \\
\hline GSA synthetase & gltX, hemA & $\begin{array}{l}\mathrm{GLU}+\mathrm{ATP}+\mathrm{NADPH} \rightarrow \mathrm{GSA}+\mathrm{AMP}+\mathrm{PPI} \\
+\mathrm{NADP}\end{array}$ & Beale, 1996 \\
\hline GSA aminotransferase & hemL & $\mathrm{GSA} \rightarrow \mathrm{ALAV}$ & Beale, 1996 \\
\hline Porphyrinogen synthetase & hemBCD & $8 \mathrm{ALAV} \rightarrow \mathrm{PORPH}+\mathrm{NH} 3$ & Beale, 1996 \\
\hline \multicolumn{4}{|l|}{$\begin{array}{l}\text { Biosynthesis of lippopolysaccharide and } \\
\text { murein }\end{array}$} \\
\hline Glutamine fructose- $6-P$ transaminase & $\operatorname{glm} S$ & $\mathrm{~F} 6 \mathrm{P}+\mathrm{GLN} \rightarrow \mathrm{GLU}+\mathrm{GA} 6 \mathrm{P}$ & Raetz, 1996 \\
\hline Glucosamine- $P$ acetyl transferase & $g \operatorname{lm} U$ & $\mathrm{GA} 6 \mathrm{P}+\mathrm{ACCOA} \rightarrow \mathrm{AGA} 6 \mathrm{P}+\mathrm{COA}$ & Raetz, 1996 \\
\hline Acetyl glucosamine mutase & $g \operatorname{lm} U$ & AGA6P $\leftrightarrow$ AGA1P & Raetz, 1996 \\
\hline $\begin{array}{l}\text { UDP } N \text {-acetylglucosamine } \\
\text { pyrophorylase }\end{array}$ & & AGA1P + UTP $\leftrightarrow$ PPI + UDPGA & \\
\hline $\begin{array}{l}\text { UDP } N \text {-acetylglucosamine } \\
\text { 4-epimerase }\end{array}$ & & $\mathrm{UDPGA} \leftrightarrow \mathrm{UDPGLN}$ & \\
\hline$N$-Acylglucosamine-6-P 2-epimerase & $k d s A$ & UDPGA + PEP $\leftrightarrow \mathrm{PI}+$ UDPGC & Raetz, 1996 \\
\hline $\begin{array}{l}\text { UDP- } N \text {-acetylmuramate } \\
\text { dehydrogenase }\end{array}$ & & UDPGC + NADH $\rightarrow$ UDPAM + NAD & \\
\hline $\begin{array}{l}\text { CMP-2-keto-3-deoxyoctanoate } \\
\text { synthase }\end{array}$ & $k d s B$ & $\mathrm{R} 5 \mathrm{P}+\mathrm{PEP}+\mathrm{CTP} \rightarrow 2 \mathrm{PI}+\mathrm{PPI}+\mathrm{CMPKDO}$ & Raetz, 1996 \\
\hline $\begin{array}{l}\text { Isomerase+mutase+pyropho- } \\
\text { phorylase+epimerase }\end{array}$ & & $\mathrm{S} 7 \mathrm{P}+\mathrm{ATP} \leftrightarrow \mathrm{ADPHEP}+\mathrm{PPI}$ & \\
\hline Ethanolamine phosphotransferase & & $\mathrm{PE}+\mathrm{CMP} \leftrightarrow \mathrm{CDPETN}+\mathrm{DGR}$ & Michal, 1993 \\
\hline Phosphatidate phosphatase & & $\mathrm{PA} \leftrightarrow \mathrm{PI}+\mathrm{DGR}$ & Michal, 1993 \\
\hline Lyposaccharide synthetase & & $\begin{array}{l}3 \mathrm{UDPGLN}+5 \mathrm{C} 14: 0+2 \mathrm{ATP}+3 \mathrm{CMPKDO} \\
+\mathrm{CDPETN}+3 \mathrm{ADPHEP}+2 \mathrm{UDPG}+\mathrm{PE}+2 \\
\mathrm{UDPGAL} \rightarrow 2 \mathrm{AC}+\mathrm{UMP}+6 \mathrm{UDP}+5 \mathrm{ADP} \\
+3 \mathrm{CMP}+\mathrm{DGR}+\mathrm{LPS}\end{array}$ & \\
\hline
\end{tabular}


APPENDIX A: CONTINUED

\begin{tabular}{|c|c|c|c|}
\hline Enzyme & Gene & Pathway & Reference \\
\hline UDP glucose synthase & & $\mathrm{G} 1 \mathrm{P}+\mathrm{UTP} \rightarrow \mathrm{PPI}+\mathrm{UDPG}$ & \\
\hline UDP galactose synthase & & $\mathrm{G} 1 \mathrm{P}+\mathrm{UTP} \leftrightarrow \mathrm{PPI}+\mathrm{UDPGAL}$ & \\
\hline Murein synthetase & & $\begin{array}{l}\text { UDPGA + UDPAM + } 2 \text { ALA + D26PIM + GLU } \\
+5 \mathrm{ATP} \rightarrow \mathrm{PEPTIDO}+5 \mathrm{ADP}+5 \mathrm{PI}+2 \mathrm{UDP}\end{array}$ & \\
\hline \multicolumn{4}{|l|}{$\begin{array}{l}\text { Polyphosphate and pyrophosphate } \\
\text { metabolism }\end{array}$} \\
\hline Pyrophosphatase & ppa & $\mathrm{PPI} \rightarrow 2$ PI & Wanner, 1996 \\
\hline Polyphosphate kinase & $p p k$ & $1000 \mathrm{ATP} \leftrightarrow 1000 \mathrm{ADP}+\mathrm{POLYP}$ & Wanner, 1996 \\
\hline Polyphosphatase & $p p x$ & POLYP $\rightarrow$ 1000PI & Wanner, 1996 \\
\hline \multicolumn{4}{|l|}{ Transport reactions } \\
\hline Ammonia transport & & $\mathrm{NH} 3$ ext $+\mathrm{Hext} \leftrightarrow \mathrm{NH} 3$ & Silver, 1996 \\
\hline Sulfate transport & & $\mathrm{H} 2 \mathrm{SO} 4 \mathrm{ext} \leftrightarrow \mathrm{H} 2 \mathrm{SO} 4$ & \\
\hline Phosphate transport & pit & PIext + Hext $\leftrightarrow$ PI & Wanner, 1996 \\
\hline Acetate transport & & $\mathrm{ACext}+\mathrm{Hext} \leftrightarrow \mathrm{AC}$ & \\
\hline Lactate transport & & $\mathrm{LACext}+\mathrm{Hext} \leftrightarrow \mathrm{LAC}$ & \\
\hline Formate transport & & FORMATEext + Hext $\leftrightarrow$ FORMATE & \\
\hline Ethanol transport & & ETHANOLext $\leftrightarrow$ ETHANOL & \\
\hline Succinate transport & & SUCCext + Hext $\leftrightarrow$ SUCC & \\
\hline D-Glyceraldehyde transport & & GLALext + Hext $\leftrightarrow$ GLAL & \\
\hline Glucose transport & & GLCext $\leftrightarrow$ GLC & \\
\hline Carbon dioxide transport & & $\mathrm{CO}_{2} \mathrm{ext} \leftrightarrow \mathrm{CO}_{2}$ & \\
\hline Oxygen transport & & $\mathrm{O}_{2} \operatorname{ext} \leftrightarrow \mathrm{O}_{2}$ & \\
\hline \multicolumn{4}{|l|}{ Glycerol metabolism } \\
\hline Glycerol kinase & & $\mathrm{GL}+\mathrm{ATP} \leftrightarrow \mathrm{GL} 3 \mathrm{P}+\mathrm{ADP}$ & Karp et al., 1996 \\
\hline Glycerol-3-phosphate dehydrogenase & & $\mathrm{GL} 3 \mathrm{P}+\mathrm{FAD} \rightarrow \mathrm{T} 3 \mathrm{P} 2+\mathrm{FADH} 2$ & Karp et al., 1996 \\
\hline
\end{tabular}

\section{APPENDIX B: METABOLITE DEFINITIONS}

\begin{tabular}{|c|c|}
\hline Abbreviation & Compound \\
\hline 13P2DG & $1,3-P$-D glycerate \\
\hline 2K3D6PG & 2-Dehydro-3-deoxy-6- $P$-gluconate \\
\hline $2 \mathrm{O} 6 \mathrm{H}$ & 2-Octaprenol 6-hydroxyphenol \\
\hline 2PDGL & 2-P-D glycerate \\
\hline 2PPP & 2-Polyprenylphenol \\
\hline 3DDAH7P & 3-Deoxy-D-arabinoheptulosonate-7-phosphate \\
\hline 3PDGL & $3 P$-D glycerate \\
\hline 3PSER & 3-Phosphoserine \\
\hline 3PSME & $o$ (1-Carboxyvinyl)-3-D-shikimate \\
\hline $4 \mathrm{HBZ}$ & 4-Hydroxybenzoate \\
\hline 5MTA & 5'-Methylthioadenosine \\
\hline A6RP & 5-Amino-6-ribitylamino-2,4(1H,3H)-pyrimidinedione \\
\hline A6RP5P & $\begin{array}{l}\text { 5-Amino-6-ribosylamino-2,4(1H,3H)-pyrimidinedione } \\
\text { 5'-phosphate }\end{array}$ \\
\hline A6RP5P2 & $\begin{array}{l}\text { 5-Amino-6-ribitylamino-2,4(1H,3H)-pyrimidinedione } \\
5 \text { '-phosphate }\end{array}$ \\
\hline $\mathrm{AABK}$ & 2-Amino-3-ketobutyrate \\
\hline ABUT & 2-Aceto-2-hydroxybutyrate \\
\hline $\mathrm{AC}$ & Acetate \\
\hline $\mathrm{ACACP}$ & Acetyl-ACP \\
\hline ACAL & Acetaldehyde \\
\hline $\mathrm{ACCOA}$ & Acetyl-CoA \\
\hline ACTP & Acetyl-phosphate \\
\hline $\mathrm{ADN}$ & Adenosine \\
\hline ADP & Adenosine diphosphate \\
\hline ADPHEP & ADP-mannoheptose \\
\hline AGA1P & $N$-Acetyl-D-glucosamine-1-phosphate \\
\hline AGA6P & $N$-Acetyl-D-glucosamine-6-phosphate \\
\hline AHHMD & $\begin{array}{l}\text { 2-Amino-4-hydroxy-6-hydroxymethyl } \\
\text { dihydropteridine-pyrophosphate }\end{array}$ \\
\hline AHHMP & 2-Amino-4-hydroxy-6-hydroxymethyl dihydropteridine \\
\hline
\end{tabular}

APPENDIX B: CONTINUED

\begin{tabular}{|c|c|}
\hline Abbreviation & Compound \\
\hline AHTD & $\begin{array}{l}\text { 2-Amino-4-hydroxy-6-(erythro-1-2-3-trihydroxypropyl) } \\
\text { dihydropteridine-phosphate }\end{array}$ \\
\hline AICAR & 5-Phosphoribosyl-5-amino-4-imidazole carboxamide \\
\hline AIR & 5-Phosphoribosyl-5-aminoimidazole \\
\hline $\mathrm{AKG}$ & $\alpha$-Ketoglutarate \\
\hline ALA & Alanine \\
\hline ALAV & $\delta$-Amonolevulinate \\
\hline AMP & Adenosine monophosphate \\
\hline $\mathrm{AN}$ & Anthranilate \\
\hline APS & Adenylyl sulfate \\
\hline ARG & Arginine \\
\hline ARGSUCC & 1-Arginiosuccinate \\
\hline ASER & $o$-Acetylserine \\
\hline ASN & Asparagine \\
\hline ASP & Aspartate \\
\hline ASPSA & Aspartate $\beta$-semialdehyde \\
\hline ASUC & Adenylsuccinate \\
\hline ATP & Adenosine triphosphate \\
\hline BASP & $\beta$-Aspartyl-phosphate \\
\hline C14:0ACP & Myristic acid ACP \\
\hline C14:1ACP & $\beta$-Hydroxymyristic acid ACP \\
\hline C16:0ACP & Palmitic acid ACP \\
\hline C16:1ACP & Palmitoleic acid ACP \\
\hline C18:1ACP & cis-Vaccenic acid ACP \\
\hline CAASP & Carbamoyl aspartate \\
\hline CAP & Carbamoyl phosphate \\
\hline CBHCAP & 3-Carboxy-3-hydroxy-isocaproate \\
\hline CDP & Cytidine diphosphate \\
\hline CDPDG & CDP-2-Diacylglycerol \\
\hline CDPETN & CDP-Ethanolamine \\
\hline CHOR & Chorismate \\
\hline
\end{tabular}


APPENDIX B: CONTINUED

\begin{tabular}{|c|c|}
\hline Abbreviation & Compound \\
\hline CITR & Citrulline \\
\hline CL & Cardiolypin \\
\hline CMP & Cytidine monophosphate \\
\hline CMPKDO & CMP-2-Keto-3-deoxyoctanoate \\
\hline $\mathrm{CO} 2$ & Carbon dioxide \\
\hline $\mathrm{COA}$ & Coenzyme A-SH \\
\hline CPAD5P & 1-o-Carboxyphenylamino 1-deoxyribulose-5-phosphate \\
\hline CTP & Cytidine triphosphate \\
\hline CYS & Cysteine \\
\hline D23PIC & 2,3-Dihydrodipicolinate \\
\hline D26PIM & L,L-2,6-Diaminopimelate \\
\hline D6PGC & D-6-Phosphoglucono- $\delta$-lactone \\
\hline D6PGL & D-6-Phosphogluconate \\
\hline D6RP5P & $\begin{array}{l}\text { 2,5-Diamino-6-ribosylamino-4(3H)-pyrimidinedione } \\
\text { 5'-phosphate }\end{array}$ \\
\hline D8RL & 6,7-Dimethyl-8-ribityllumazine \\
\hline DADP & Deoxyadenosine diphosphate \\
\hline DANAD & Deamido-NAD \\
\hline DATP & Deoxyadenosine triphosphate \\
\hline DB4P & L-3,4-Dihydroxy-2-butanone-4-phosphate \\
\hline DCDP & Deoxycytidine diphosphate \\
\hline DCTP & Deoxycytidine triphosphate \\
\hline DGDP & Deoxyguanosine diphosphate \\
\hline DGMP & 2-Deoxy-guanosine-5-phosphate \\
\hline DGR & D-1,2-Diacylglycerol \\
\hline DGTP & Deoxyguanosine triphosphate \\
\hline DHD & 7,8-Dihydropteroate \\
\hline DHF & Dihydrofolate \\
\hline DHMVA & 2,3-Dihydroxy-3-methyl-valerate \\
\hline DHP & Dihydroneopterin \\
\hline DHSK & Dehydroshikimate \\
\hline DHVAL & $\alpha, \beta$-Dihydroxy-isovalerate \\
\hline DIMGP & $d$-Erythroimidazoleglycerol-phosphate \\
\hline DOROA & Dihydroorotic acid \\
\hline DQT & 3-Dehydroquinate \\
\hline DSAM & Decarboxylated SAM \\
\hline DUDP & Deoxyuridine diphosphate \\
\hline DUMP & Deoxyuridine monophosphate \\
\hline DUTP & Deoxyuridine triphosphate \\
\hline $\mathrm{E} 4 \mathrm{P}$ & Erythrose 4-phosphate \\
\hline $\mathrm{EFF}$ & Efficiency \\
\hline ETHANOL & Ethanol \\
\hline F16P & Fructose 1,6-diphosphate \\
\hline F6P & Fructose 6-phosphate \\
\hline FADH & Flavin adenine dinucleotide \\
\hline FGAM & 5-Phosphoribosyl- $N$-formylgycineamidine \\
\hline FGAR & 5-Phosphoribosyl- $N$-formylglycineamide \\
\hline FMN & Riboflavin $5^{\prime}$-phosphate \\
\hline FORMATE & Formate \\
\hline FTHF & 10-Formyl-tetrahydrofolate \\
\hline FUM & Fumarate \\
\hline G1P & Glucose 1-phosphate \\
\hline G6P & Glucose 6-phosphate \\
\hline GA6P & Glucosamine-6-phosphate \\
\hline GAR & 5-Phosphoribosyl glycineamide \\
\hline GDP & Guanosine diphosphate \\
\hline GGPP & Geranylgeranyl pyrophosphate \\
\hline GL & Glycerol \\
\hline GL3P & Glycoden 3-phosphate \\
\hline GLAL & D-Glyceraldehyde \\
\hline GLC & Glucose \\
\hline GLN & Glutamine \\
\hline GLU & Glutamate \\
\hline GLUGSAL & L-Glutamate $\gamma$-semialdehyde \\
\hline
\end{tabular}

APPENDIX B: CONTINUED

\begin{tabular}{|c|c|}
\hline Abbreviation & Compound \\
\hline GLX & Glyoxylate \\
\hline GLY & Glycine \\
\hline GLYCOGEN & Glycogen \\
\hline GMP & Guanosine monophosphate \\
\hline GSA & Glutamate 1-semialdehyde \\
\hline GTP & Guanosine triphosphate \\
\hline $\mathrm{H} 2 \mathrm{~S}$ & Hydrogen sulfide \\
\hline $\mathrm{H} 2 \mathrm{SO} 3$ & Hydrogen sulfite \\
\hline $\mathrm{H} 2 \mathrm{SO} 4$ & Hydrogen sulfate \\
\hline HCYS & Homocysteine \\
\hline HEXT & External $\mathrm{H}^{+}$ \\
\hline HIS & Histidine \\
\hline HISOL & Histidinol \\
\hline HISOL-P & 1-Histidinol-phosphate \\
\hline HMGCOA & 3-Hydroxy-3-methyl-glutaryl CoA \\
\hline HPHPYR & para-Hydroxy phenyl pyruvate \\
\hline HSER & Homoserine \\
\hline ICIT & Isocitrate \\
\hline IGP & Indole glycerol phosphate \\
\hline ILE & Isoleucine \\
\hline IMACP & Imidazole acetyl-phosphate \\
\hline IMP & Inosine monophosphate \\
\hline IPPP & Isopentyl pyrophosphate \\
\hline IPPMAL & 3-Isopropylmalate \\
\hline ISOVCOA & Isovaleryl-CoA \\
\hline LA & Lipoamide \\
\hline $\mathrm{LAC}$ & Lactate \\
\hline LEU & Leucine \\
\hline LPS & Lipposaccharide \\
\hline LYS & l-Lysine \\
\hline MAL & Malate \\
\hline MALACP & Malonyl-ACP \\
\hline MALCOA & Malonyl-CoA \\
\hline MCCOA & 3-Methyl crotonyl-CoA \\
\hline MDAP & meso-Diaminopimelate \\
\hline MET & Methionine \\
\hline METHF & 5,10-Methenyl tetrahydrofolate \\
\hline METTHF & 5,10-Methylene tetrahydrofolate \\
\hline MTHF & 5-Methyl tetrahydrofolate \\
\hline NAARON & $N$ - $\alpha$-Acetyl ornithine \\
\hline NADH & Nicotinamide adenine dinucleotide \\
\hline NADPH & Nicotinamide adenine dinucleotide phosphate \\
\hline NAGLU & $N$-Acetyl glutamate \\
\hline NAGLUYP & $N$-Acetyl glutamyl-phosphate \\
\hline NAGLUSAL & $N$-Acetyl glutamate semialdehyde \\
\hline NH3 & Ammonia \\
\hline NICNT & Nicotinate nucleotide \\
\hline NPRAN & $N$-5-Phosphoribosyl-antranilate \\
\hline NS26DP & $N$-Succinyl-1,1-2,6-diaminopimelate \\
\hline NS2A6O & $N$-Succinyl-2-amino-6-ketopimelate \\
\hline $\mathrm{O} 2$ & Oxygen \\
\hline $\mathrm{OA}$ & Oxaloacetate \\
\hline OBUT & Oxobutyrate \\
\hline OICAP & 2-Oxoisocaproate \\
\hline OIVAL & Oxoisovalerate \\
\hline OMP & Orotidylate \\
\hline OMVAL & Oxomethylvalerate \\
\hline ORN & Ornithine \\
\hline OROA & Orotic acid \\
\hline OSLHSER & $o$-Succinyl-L-homoserine \\
\hline PA & Phosphatidyl acid \\
\hline PAP & Adenosine-3,5-diphosphate \\
\hline PAPS & 3-Phosphoadenylyl sulfate \\
\hline PE & Phosphatidyl ethanolamine \\
\hline
\end{tabular}


APPENDIX B: CONTINUED

\begin{tabular}{|c|c|}
\hline Abbreviation & Compound \\
\hline PEP & Phosphoenolpyruvate \\
\hline PEPTIDO & Peptidoglycan \\
\hline PG & Phosphatidyl glycerol \\
\hline PGP & 1-1-Phosphatidyl-glycerol-phosphate \\
\hline PHE & Phenylalanine \\
\hline PHEN & Prephenate \\
\hline PHP & 3-Phosphohydroxypyruvate \\
\hline PHPYR & Phenyl pyruvate \\
\hline PHSER & $o$-Phospho-l-homoserine \\
\hline PI & Phosphate (inorganic) \\
\hline PIP26DX & $\delta$-Pieperidine-2,6-dicarboxylate \\
\hline POLYP & Polyphosphate \\
\hline PORPH & Porphyrinogen \\
\hline PPI & Pyrophosphate \\
\hline PRAM & 5-Phospho- $\beta$-D-ribosyl amine \\
\hline PRBAMP & Phosphoribosyl-AMP \\
\hline PRBATP & Phosphoribosyl-ATP \\
\hline PRFICA & 5-Phosphoribosyl-formamido-4-imidazole carboxamide \\
\hline PRFP & Phosphoribosyl-formimino-AICAR-phosphate \\
\hline PRLP & Phosphoribulosyl-formimino-AICAR-phosphate \\
\hline PRO & Proline \\
\hline PRPP & Phosphoribosyl pyrophosphate \\
\hline PRSCAIM & 5-Phosphoribosy-14- $N$-succinocarboxyamide-5-amino \\
\hline PS & Phosphatidyl serine \\
\hline PTRSC & Putrescine \\
\hline PYR & Pyruvate \\
\hline Q & Ubiquinone \\
\hline $\mathrm{QH} 2$ & Ubiquinol \\
\hline QNL & Quinolate \\
\hline $\mathrm{R} 5 \mathrm{P}$ & Ribose 5-phosphate \\
\hline RCAIM & 5-p-Ribosyl-4-carboxy-5-aminoimidazole \\
\hline RIBOFLAVIN & Riflavin \\
\hline RL5P & D-Ribulose 5-phosphate \\
\hline S7P & D-Sedoheptulose-7- $P$ \\
\hline $\mathrm{SAH}$ & $s$-Adenosyl homocystine \\
\hline SAM & $s$-Adenosyl methionine \\
\hline SER & Serine \\
\hline SME & Shikimate \\
\hline SME5P & Shikimate-5-phosphate \\
\hline SPRMD & Spermidine \\
\hline SUCC & Succinate \\
\hline SUCCOA & Succinyl-CoA \\
\hline T3P1 & Glyceraldehyde-3-phosphate \\
\hline T3P2 & Dihydroxyacetone phosphate \\
\hline TDP & Thymidine-5-diphosphate \\
\hline THF & Tetrahydrofolate \\
\hline THR & Threonine \\
\hline TMGCOA & trans-3-Methyl-glutaconyl-CoA \\
\hline TMP & Thymidine-5-monophosphate \\
\hline TRP & Tryptophan \\
\hline TTP & Thymidine-5-triphosphate \\
\hline TYR & Tyrosine \\
\hline UDP & Uridine diphosphate \\
\hline UDPAM & UDP-Acetylmuramate \\
\hline UDPGA & UDP- $N$-Acetylglucosamine \\
\hline UDPGAL & UDP $N$-Acetylgalactosamine \\
\hline UDPGC & UDP $N$-Acetylglucosamine-enolpyruvate \\
\hline UDPGLN & UDP $N$-Actylglucosamine \\
\hline UMP & Uridine monophosphate \\
\hline UREA & Urea \\
\hline UTP & Uridine triphosphate \\
\hline VAL & Valine \\
\hline $\mathrm{X} 5 \mathrm{P}$ & Xylulose-5-phosphate \\
\hline XMP & Xantosine monophosphate \\
\hline
\end{tabular}

We acknowledge the National Science Foundation (BES9502495) for funding.

\section{References}

Andersen, K. B., von Meyenburg, K. v. 1980. Are growth rates of Escherichia coli in batch cultures limited by respiration? J. Bacteriol. 144: 114-123.

Bacher, A., Eberhardt, S., Richter, G. 1996. Biosynthesis of riboflavin, pp. 657-664. In: F. C. Neidhardt, R. Curtiss, J. L. Ingraham, E. C. C. Lin, K. B. Low, B. Magasanik, W. S. Reznikoff, M. Riley, M. Schaechter, and H. E. Umbarger (eds.), Escherichia coli and Salmonella. Cellular and molecular biology. ASM Press, Washington, D.C.

Ballesta, J. P. G., Schaechter, M. 1971. Effect of shift-down and growth inhibition on phospholipid metabolism of Escherichia coli. J. Bacteriol. 107: 251-258.

Beale, S. I. 1996. Biosynthesis of hemes, pp. 731-748. In: F. C. Neidhardt, R. Curtiss, J. L. Ingraham, E. C. C. Lin, K. B. Low, B. Magasanik, W. S. Reznikoff, M. Riley, M. Schaechter, and H. E. Umbarger (eds.), Escherichia coli and Salmonella. Cellular and molecular biology. ASM Press, Washington, D.C.

Blanch, H. W., Clark, D. S. 1996. Biochemical engineering. Marcel Dekker, New York.

Bock, A., Sawers, G. 1996. Fermentation, pp. 262-282. In: F. C. Neidhardt, R. Curtiss, J. L. Ingraham, E. C. C. Lin, K. B. Low, B. Magasanik, W. S. Reznikoff, M. Riley, M. Schaechter, and H. E. Umbarger (eds.), Escherichia coli and Salmonella. Cellular and molecular biology. ASM Press, Washington, D.C.

Bremer, H., Dennis, P. P. 1987. Modulation of chemical composition and other parameters of the cell by growth rate, pp. 1527-1542. In: F. C. Neidhardt (ed.), Escherichia coli and Salmonella typhimurium: Cellular and molecular biology. American Society for Microbiology, Washington, D.C.

Bremer, H., Dennis, P. P. 1996. Modulation of chemical composition and other parameters of the cell by growth rate, pp. 1553-1569. In: F. C. Neidhardt, R. Curtiss, J. L. Ingraham, E. C. C. Lin, K. B. Low, B. Magasanik, W. S. Reznikoff, M. Riley, M. Schaechter, and H. E. Umbarger (eds.), Escherichia coli and Salmonella. Cellular and molecular biology. ASM Press, Washington, D.C.

Bright-Gaertner, E., Proulx, P. 1972. Metabolism of phosphoglycerides in Escherichia coli during growth at $37^{\circ}$ and during a cold-induced lag phase. Biochim. Biophys. Acta 270: 40-49.

Brunschede, H., Dove, T. L., Bremer, H. 1977. Establishment of exponential growth after a nutritional shift-up in Escherichia coli b/r: Accumulation of deoxyribonucleic acid, ribonucleic acid, and protein. J. Bacteriol. 129: 1020-1033.

Characklis, W. G., Marshall, K. C. (eds.). 1989. Biofilms. Wiley series in ecological and applied microbiology. Wiley, New York.

Cronan, J. E., LaPorte, D. 1996. Tricarboxylic acid cycle and glyoxylate bypass, pp. 206-216. In: F. C. Neidhardt, R. Curtiss, J. L. Ingraham, E. C. C. Lin, K. B. Low, B. Magasanik, W. S. Reznikoff, M. Riley, M. Schaechter, and H. E. Umbarger (eds.), Escherichia coli and Salmonella. Cellular and molecular biology. ASM Press, Washington, D.C.

Cronan, J. E., Rock, C. O. 1996. Biosynthesis of membrane lipids, pp. 612-636. In: F. C. Neidhardt, R. Curtiss, J. L. Ingraham, E. C. C. Lin, K. B. Low, B. Magasanik, W. S. Reznikoff, M. Riley, M. Schaechter, and H. E. Umbarger (eds.), Escherichia coli and Salmonella. Cellular and molecular biology. ASM Press, Washington, D.C.

Donachie, W. D., Robinson, A. C. 1987. Cell division: Parameter values and the process, pp. 1578-1593. In: F. C. Neidhardt (ed.), Escherichia coli and Salmonella typhimurium: Cellular and molecular biology. American Society for Microbiology, Washington, D.C.

Eckert, R. E., Schaechter, M. 1965. Bacterial growth under conditions of limited nutrition. Ann. NY Acad. Sci. 102: 549-563.

Fraenkel, D. G. 1996. Glycolysis, pp. 189-198. In: F. C. Neidhardt, R. Curtiss, J. L. Ingraham, E. C. C. Lin, K. B. Low, B. Magasanik, W. S. Reznikoff, M. Riley, M. Schaechter, and H. E. Umbarger (eds.), Esch- 
erichia coli and Salmonella. Cellular and molecular biology. ASM Press, Washington, D.C.

Gennis, R. B., Stewart, V. 1996. Respiration, pp. 217-261. In: F. C. Neidhardt, R. Curtiss, J. L. Ingraham, E. C. C. Lin, K. B. Low, B. Magasanik, W. S. Reznikoff, M. Riley, M. Schaechter, and H. E. Umbarger (eds.), Escherichia coli and Salmonella. Cellular and molecular biology. ASM Press, Washington, D.C.

Glansdorf, N. 1996. Biosynthesis of arginine and polyamines, pp. 408-433. In: F. C. Neidhardt, R. Curtiss, J. L. Ingraham, E. C. C. Lin, K. B. Low, B. Magasanik, W. S. Reznikoff, M. Riley, M. Schaechter, and H. E. Umbarger (eds.), Escherichia coli and Salmonella. Cellular and molecular biology. ASM Press, Washington, D.C.

Green, J. M., Nichols, B. P., Matthews, R. 1996. Folate biosynthesis, reduction, and polyglutamylation, pp. 665-673. In: F. C. Neidhardt, R. Curtiss, J. L. Ingraham, E. C. C. Lin, K. B. Low, B. Magasanik, W. S. Reznikoff, M. Riley, M. Schaechter, and H. E. Umbarger (eds.), Escherichia coli and Salmonella. Cellular and molecular biology. ASM Press, Washington, D.C.

Greene, R. C. 1996. Biosynthesis of methionine, pp. 542-560. In: F. C. Neidhardt, R. Curtiss, J. L. Ingraham, E. C. C. Lin, K. B. Low, B. Magasanik, W. S. Reznikoff, M. Riley, M. Schaechter, and H. E. Umbarger (eds.), Escherichia coli and Salmonella. Cellular and molecular biology. ASM Press, Washington, D.C.

Harold, F. M., Maloney, P. C. 1996. Energy transduction by ion currents, pp. 283-306. In: F. C. Neidhardt, R. Curtiss, J. L. Ingraham, E. C. C. Lin, K. B. Low, B. Magasanik, W. S. Reznikoff, M. Riley, M. Schaechter, and H. E. Umbarger (eds.), Escherichia coli and Salmonella. Cellular and molecular biology. ASM Press, Washington, D.C.

Harrison, D. E. F., Loveless, J. E. 1971. The effect of growth conditions on respiratory activity and growth efficiency in facultative anaerobes grown in chemostat culture. J. Gen. Microbiol. 68: 35-43.

Hempfling, W. P., Mainzer, S. E. 1975. Effects of varying the carbon source limiting growth on yield and maintenance characteristics of Escherichia coli in continuous culture. J. Bacteriol. 123: 1076-1087.

Herbert, D., Kornberg, H. L. 1976. Glucose transport as rate-limiting step in the growth of Escherichia coli on glucose. Biochem. J. 156: 477-480.

Holme, T. 1957. Continuous culture studies on glycogen synthesis in Escherichia coli B. Acta Chem. Scand. 11: 763-775.

IBM. 1992. IBM: Optimization subroutine library, guide and reference, release 2. IBM Corp., White Plains, NY.

Jackowski, S. 1996. Biosynthesis of pantothenic acid and coenzyme A, pp. 687-694. In: F. C. Neidhardt, R. Curtiss, J. L. Ingraham, E. C. C. Lin, K. B. Low, B. Magasanik, W. S. Reznikoff, M. Riley, M. Schaechter, and H. E. Umbarger (eds.), Escherichia coli and Salmonella. Cellular and molecular biology. ASM Press, Washington, D.C.

Kadner, R. J. 1996. Cytoplasmic membrane, pp. 58-87. In: F. C. Neidhardt, R. Curtiss, J. L. Ingraham, E. C. C. Lin, K. B. Low, B. Magasanik, W. S. Reznikoff, M. Riley, M. Schaechter, and H. E. Umbarger (eds.), Escherichia coli and Salmonella. Cellular and molecular biology. ASM Press, Washington, D.C.

Kanemasa, Y., Akamatsu, Y., Nojima, S. 1967. Composition and turnover of the phospholipids in Escherichia coli. Biochim. Biophys. Acta 144: 382-390.

Karp, P. D., Riley, M., Paley, S. M., Pelligrinitoole, A. 1996. Ecocyc—An encyclopedia of Escherichia coli genes and metabolism. Nucleic Acids Res. 24: 32-39.

Kessler, D., Knappe, J. 1996. Anaerobic dissimilation of pyruvate, pp. 199-205. In: F. C. Neidhardt, R. Curtiss, J. L. Ingraham, E. C. C. Lin, K. B. Low, B. Magasanik, W. S. Reznikoff, M. Riley, M. Schaechter, and H. E. Umbarger (eds.), Escherichia coli and Salmonella. Cellular and molecular biology. ASM Press, Washington, D.C.

Kredich, N. M. 1996. Biosynthesis of cysteine, pp. 514-527. In: F. C. Neidhardt, R. Curtiss, J. L. Ingraham, E. C. C. Lin, K. B. Low, B. Magasanik, W. S. Reznikoff, M. Riley, M. Schaechter, and H. E. Umbarger (eds.), Escherichia coli and Salmonella. Cellular and molecular biology. ASM Press, Washington, D.C.

Leisinger, T. 1996. Biosynthesis of proline, pp. 434-441. In: F. C.
Neidhardt, R. Curtiss, J. L. Ingraham, E. C. C. Lin, K. B. Low, B. Magasanik, W. S. Reznikoff, M. Riley, M. Schaechter, and H. E. Umbarger (eds.), Escherichia coli and Salmonella. Cellular and molecular biology. ASM Press, Washington, D.C.

Lowry, O. H., Carter, J., Ward, J. B., Glaser, L. 1971. The effect of carbon and nitrogen sources on the level of metabolic intermediates in Escherichia coli. J. Biol. Chem. 246: 6511-6521.

Luenberger, D. G. 1984. Linear and nonlinear programming, 2nd edition. Addison-Wesley, Reading, MA.

Majewski, R. A., Domach, M. M. 1990. Simple constrained-optimization view of acetate overflow in E. coli. Biotechnol. Bioeng. 35: 732-738.

Maloney, P. C. 1987. Coupling to an energized membrane: Role of ionmotive gradients in the transduction of metabolic energy. In: F. C. Neidhardt (ed.), Escherichia coli and Salmonella typhimurium: Cellular and molecular biology. ASM, Washington, D.C.

Marr, A. G. 1991. Growth rate of Escherichia coli. Microbiol. Rev. O: 316-333.

Matthews, R. 1996. One-carbon metabolism, pp. 600-611. In: F. C. Neidhardt, R. Curtiss, J. L. Ingraham, E. C. C. Lin, K. B. Low, B. Magasanik, W. S. Reznikoff, M. Riley, M. Schaechter, and H. E. Umbarger (eds.), Escherichia coli and Salmonella. Cellular and molecular biology. ASM Press, Washington, D.C.

Mavis, R. D., Vagelos, P. R. 1972. The effect of phospholipid fatty acid composition on membranous enzymes in Escherichia coli. J. Biol. Chem. 247: 652-659.

Meganathan, R. 1996. Biosynthesis of the isoprenoid quinones menaquinone (vitamin K2) and ubiquinone (coenzyme Q). In: F. C. Neidhardt, R. Curtiss, J. L. Ingraham, E. C. C. Lin, K. B. Low, B. Magasanik, W. S. Reznikoff, M. Riley, M. Schaechter, and H. E. Umbarger (eds.), Escherichia coli and Salmonella. Cellular and molecular biology. ASM Press, Washington, D.C.

Michal, G. 1993. Biochemical pathways, 3rd edition. Boehringer Mannheim GmbH Biochemica, Place.

Neidhardt, F. C. (ed.). 1987. Chemical composition of Escherichia coli. In: F. C. Neidhardt (ed.), Escherichia coli and Salmonella typhimurium: Cellular and molecular biology. American Society for Microbiology, Washington, D.C.

Neidhardt, F. C., Ingraham, J. L., Schaechter, M. 1990. Physiology of the bacterial cell. Sinauer Associates, Sunderland, MA.

Neuhard, J., Klein, R. A. 1996. Biosynthesis and conversions of pyrimidines, pp. 580-599. In: F. C. Neidhardt, R. Curtiss, J. L. Ingraham, E. C. C. Lin, K. B. Low, B. Magasanik, W. S. Reznikoff, M. Riley, M. Schaechter, and H. E. Umbarger (eds.), Escherichia coli and Salmonella. Cellular and molecular biology. ASM Press, Washington, D.C.

Nimmo, H. G. 1987. The tricarboxylic acid cycle and anaplerotic reactions, pp. 156-167. In: F. C. Neidhardt (ed.), Escherichia coli and Salmonella typhimurium: Cellular and molecular biology. American Society for Microbiology, Washington, D.C.

Nissen, T. L., Schulze, U., Nielsen, J., Villadsen, J. 1997. Flux distributions in anaerobic, glucose-limited continuous cultures of Saccharomyces cerevisiae. Microbiology 143: 203-218.

Papoutsakis, E. T. Equations and calculations for fermentations of butyric acid bacteria. Biotechnol. Bioeng. 26: 174-187.

Patte, J.-C. 1996. Biosynthesis of threonine and lysine, pp. 528-541. In: F. C. Neidhardt, R. Curtiss, J. L. Ingraham, E. C. C. Lin, K. B. Low, B. Magasanik, W. S. Reznikoff, M. Riley, M. Schaechter, and H. E. Umbarger (eds.), Escherichia coli and Salmonella. Cellular and molecular biology. ASM Press, Washington, D.C.

Penfound, T., Foster, J. W. 1996. Biosynthesis and recycling of NAD, pp. 721-730. In: F. C. Neidhardt, R. Curtiss, J. L. Ingraham, E. C. C. Lin, K. B. Low, B. Magasanik, W. S. Reznikoff, M. Riley, M. Schaechter, and H. E. Umbarger (eds.), Escherichia coli and Salmonella. Cellular and molecular biology. ASM Press, Washington, D.C.

Pirt, S. J. 1965. The maintenance energy of bacteria in growing cultures. Proc. R. Soc. B 163: 224-231.

Pirt, S. J. 1982. Maintenance energy: A general model for energy-limited and energy-sufficient growth. Arch. Microbiol. 133: 300-302.

Pittard, A. J. 1996. Biosynthesis of aromatic amino acids, pp. 458-484. In: 
F. C. Neidhardt, R. Curtiss, J. L. Ingraham, E. C. C. Lin, K. B. Low, B Magasanik, W. S. Reznikoff, M. Riley, M. Schaechter, and H. E. Umbarger (eds.), Escherichia coli and Salmonella. Cellular and molecular biology. ASM Press, Washington, D.C.

Postma, P. W., Lengeler, J. W., Jacobson, G. R. 1996. Phosphoenolpyruvate:carbohydrate phosphotransferase systems, pp. 1149-1174. In F. C. Neidhardt, R. Curtiss, J. L. Ingraham, E. C. C. Lin, K. B. Low, B. Magasanik, W. S. Reznikoff, M. Riley, M. Schaechter, and H. E. Um20barger (eds.), Escherichia coli and Salmonella. Cellular and molecular biology. ASM Press, Washington, D.C.

Preiss, J. 1996. Regulation of glycogen biosynthesis, pp. 1015-1024. In: F. C. Neidhardt, R. Curtiss, J. L. Ingraham, E. C. C. Lin, K. B. Low, B. Magasanik, W. S. Reznikoff, M. Riley, M. Schaechter, and H. E. Umbarger (eds.), Escherichia coli and Salmonella. Cellular and molecular biology. ASM Press, Washington, D.C.

Raetz, C. R. H. 1996. Bacterial lipopolysaccharides: A remarkable family of bioactive macroamphiphiles, pp. 1035-1063. In: F. C. Neidhardt, R. Curtiss, J. L. Ingraham, E. C. C. Lin, K. B. Low, B. Magasanik, W. S Reznikoff, M. Riley, M. Schaechter, and H. E. Umbarger (eds.), Escherichia coli and Salmonella. Cellular and molecular biology. ASM Press, Washington, D.C.

Reitzer, L. J. 1996. Ammonia assimilation and the biosynthesis of glutamine, glutamate, aspartate, asparagine, L-alanine, and D-alanine, pp 391-407. In: F. C. Neidhardt, R. Curtiss, J. L. Ingraham, E. C. C. Lin, K. B. Low, B. Magasanik, W. S. Reznikoff, M. Riley, M. Schaechter, and H. E. Umbarger (eds.), Escherichia coli and Salmonella. Cellular and molecular biology. ASM Press, Washington, D.C.

Savinell, J. M., Lee, G. M., Palsson, B. O. 1989. On the orders of magnitude of epigenic dynamics and monoclonal antibody production. Bioprocess Eng. 4: 231-234.

Savinell, J. M., Palsson, B. O. 1992a. Network analysis of intermediary metabolism using linear optimization. I. Development of mathematical formalism. J. Theor. Biol. 154: 421-454.

Savinell, J. M., Palsson, B. O. 1992b. Network analysis of intermediary metabolism using linear optimization. II. Interpretation of hybridoma cell metabolism. J. Theor. Biol. 154: 455-473.

Schulze, K. L., Lipe, R. S. 1964. Relationship between substrate concentration, growth rate, and respiration rate of Escherichia coli in continuous culture. Arch. Mikrobiol. 48: 1-20.

Shehata, T. E., Marr, A. G. 1971. Effect of nutrient concentration on the growth of Escherichia coli. J. Bacteriol. 107: 201-216.

Silver, S. 1996. Transport of inorganic cations, pp. 1091-1102. In: F. C. Neidhardt, R. Curtiss, J. L. Ingraham, E. C. C. Lin, K. B. Low, B. Magasanik, W. S. Reznikoff, M. Riley, M. Schaechter, and H. E. Umbarger (eds.), Escherichia coli and Salmonella. Cellular and molecular biology. ASM Press, Washington, D.C.

Smith, M. W., Neidhardt, F. C. 1983. Protein induced by anaerobiosis in Escherichia coli. J. Bacteriol. 154: 336-343.

Stauffer, G. V. 1996. Biosynthesis of serine, glycine, and one-carbon units, pp. 506-513. In: F. C. Neidhardt, R. Curtiss, J. L. Ingraham, E. C. C. Lin, K. B. Low, B. Magasanik, W. S. Reznikoff, M. Riley, M. Schaechter, and H. E. Umbarger (eds.), Escherichia coli and Salmonella. Cellular and molecular biology. ASM Press, Washington, D.C.

Tempest, D. W., Neijssel, O. M. 1987. Growth yield and energy distribution, pp. 797-805. In: F. C. Neidhardt (ed.), Escherichia coli and Sal- monella typhimurium: Cellular and molecular biology. American Society for Microbiology, Washington, D.C.

Tsai, S. P., Lee, Y. H., Networks, M. 1988. Application of metabolic pathway stoichiometry to statistical analysis of bioreactor measurement data. Biotechnol. Bioeng. 32: 713-715.

Umbarger, H. E. 1996. Biosynthesis of the branched-chain amino acids, pp. 442-457. In: F. C. Neidhardt, R. Curtiss, J. L. Ingraham, E. C. C. Lin, K. B. Low, B. Magasanik, W. S. Reznikoff, M. Riley, M. Schaechter, and H. E. Umbarger (eds.), Escherichia coli and Salmonella. Cellular and molecular biology. ASM Press, Washington, D.C.

Vallino, J. J., Stephanopoulos, G. N. 1993. Metabolic flux distributions in Corynebacterium glutamicum during growth and lysine overproduction. Biotechnol. Bioeng. 41: 633-646.

van Gulik, W. M., Heijnen, J. J. 1995. A metabolic network stoichiometry analysis of microbial growth and product formation. Biotechnol. Bioeng. 48: 681-698.

Varma, A., Boesch, B. W., Palsson, B. O. 1993. Biochemical production capabilities of Escherichia coli. Biotechnol. Bioeng. 42: 59-73.

Varma, A., Palsson, B. O. 1993. Metabolic capabilities of Escherichia coli. 2. Optimal growth patterns. J. Theor. Biol. 165: 503-522.

Varma, A., Palsson, B. O. 1994a. Metabolic flux balancing: Basic concepts, scientific and practical use. Bio/Technology 12: 994-998.

Varma, A., Palsson, B. O. 1994b. Stoichiometric flux balance models quantitatively predict growth and metabolic by-product secretion in wild-type Escherichia coli W3110. Appl. Environ. Microbiol. 60: 3724-3731.

Varma, A., Palsson, B. O. 1995. Parametric sensitivity of stoichiometric flux balance models applied to wild-type Escherichia coli metabolism. Biotechnol. Bioeng. 45: 69-79.

Walsh, K., Koshland, D. E. 1985a. Characterization of rate-controlling steps in vivo by use of an adjustable expression vector. Proc. Natl. Acad. Sci. USA 82: 3577-3581.

Walsh, K., Koshland, D. E. 1985b. Branch point control by the phosphorylation state of isocitrate dehydrogenase. A quantitative examination of fluxes during a regulatory transition. J. Biol. Chem. 260: $8430-8437$.

Wanner, B. L. 1996. Phosphorus assimilation and control of the phosphate regulon, pp. 1357-1381. In: F. C. Neidhardt, R. Curtiss, J. L. Ingraham, E. C. C. Lin, K. B. Low, B. Magasanik, W. S. Reznikoff, M. Riley, M. Schaechter, and H. E. Umbarger (eds.), Escherichia coli and Salmonella. Cellular and molecular biology. ASM Press, Washington, D.C.

White, R. H. 1996. Biosynthesis of isoprenoids in bacteria, pp. 637-641. In: F. C. Neidhardt, R. Curtiss, J. L. Ingraham, E. C. C. Lin, K. B. Low, B. Magasanik, W. S. Reznikoff, M. Riley, M. Schaechter, and H. E. Umbarger (eds.), Escherichia coli and Salmonella. Cellular and molecular biology. ASM Press, Washington, D.C.

Winkler, M. E. 1996. Biosynthesis of histidine, pp. 485-505. In: F. C. Neidhardt, R. Curtiss, J. L. Ingraham, E. C. C. Lin, K. B. Low, B. Magasanik, W. S. Reznikoff, M. Riley, M. Schaechter, and H. E. Umbarger (eds.), Escherichia coli and Salmonella. Cellular and molecular biology. ASM Press, Washington, D.C.

Zalkin, H., Nygaard, P. 1996. Biosynthesis of purine nucleotides, pp. 561-579. In: F. C. Neidhardt, R. Curtiss, J. L. Ingraham, E. C. C. Lin, K. B. Low, B. Magasanik, W. S. Reznikoff, M. Riley, M. Schaechter, and H. E. Umbarger (eds.), Escherichia coli and Salmonella. Cellular and molecular biology. ASM Press, Washington, D.C. 